$5-1-2010$

\title{
The Effects of Two Different Post-Exercise Stretching Modalities on Delayed Onset Muscular Soreness in Adults
}

Ryan P. McGrath

How does access to this work benefit you? Let us know!

Follow this and additional works at: https://commons.und.edu/theses

Part of the Psychology Commons

\section{Recommended Citation}

McGrath, Ryan P., "The Effects of Two Different Post-Exercise Stretching Modalities on Delayed Onset Muscular Soreness in Adults" (2010). Theses and Dissertations. 1016.

https://commons.und.edu/theses/1016

This Thesis is brought to you for free and open access by the Theses, Dissertations, and Senior Projects at UND Scholarly Commons. It has been accepted for inclusion in Theses and Dissertations by an authorized administrator of UND Scholarly Commons. For more information, please contact und.commons@library.und.edu. 
THE EFEECTS OF TWO DIFFERENT POST-EXERCISE STRETCHNG MODALITIES ON DELAYED ONSET MUSCULAR SORENESS IN ADULTS

by

Ryan P. McGrath

Bachelor of Arts, Jamestown College, 2007

\author{
A Thesis \\ Submitted to the Graduate Faculty \\ of the \\ University of North Dakcta \\ in partial fulfillment of the requirements \\ for the degree of
}

Master of Science

Grand Forks, North Dakota

May

2010 
This thesis, submitted by Ryan P. McGrath in partial fulfillment of the requirements for the Degree of Master of Science from the University of North Dakota, has been read by the Faculty Advisory Committee under whom the work has been done and is hereby approved.

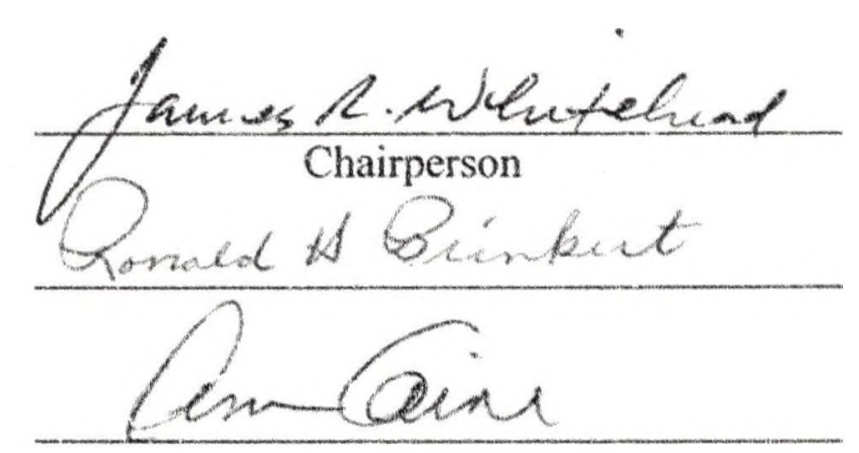

This thesis meets the standards for appearance, conforms to the style and format requirements of the Graduate School of the University of North Dakota, and is hereby approved.

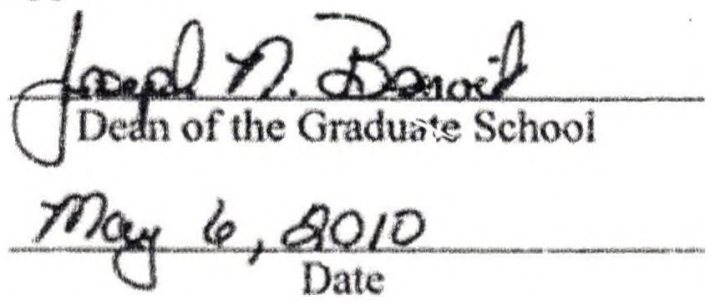




\section{Permission}

Titie The Effects of Two Different Post-Exercise Stretching Modalities on Delayed Onset Muscular Soreness in Adults

Department Kinesiology

Degree $\quad$ Master of Science

In presenting this thesis in thesis in partial fulfillment of the requirements for a graduate degree from the University of North Dakota, I agree that the library of this University shall make it freely available for inspection. I further agree that permission for extensive copying for scholarly purposes may be granted by the professor who supervised my thesis work or, in her absence, by the chairperson of the department or the dean of the Graduate School. It is understood that any copying or publication or other use of this thesis or part thereof for financial gain shall not be allowed without my written permission. It is also understood that due recognition shall be given to me and to the University of North Dakota in any scholarly use which may be made of any material in my thesis

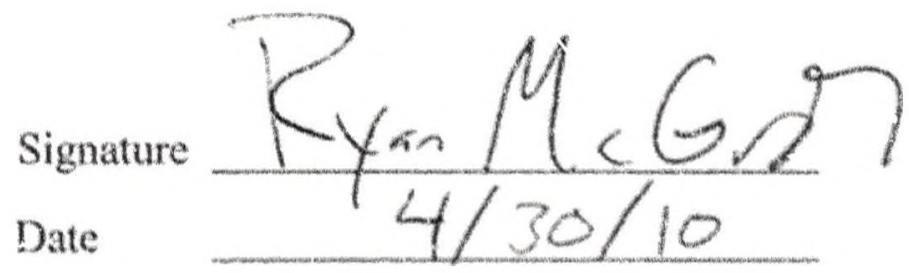


TABLE OF CONTENTS

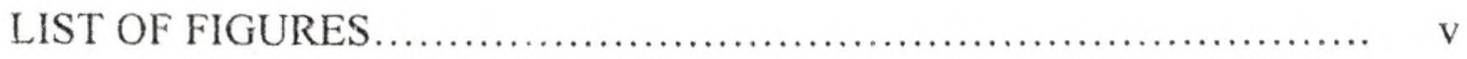

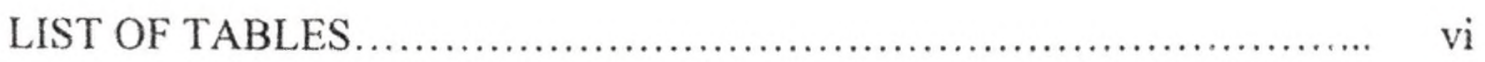

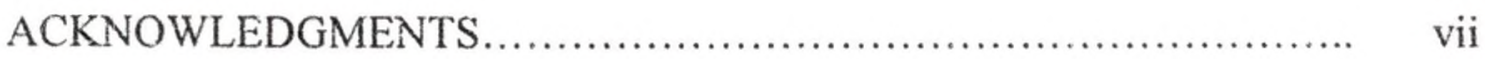

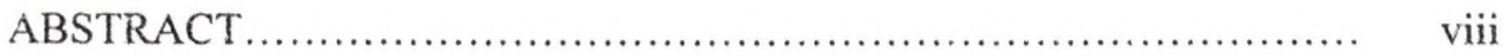

CHAPTER

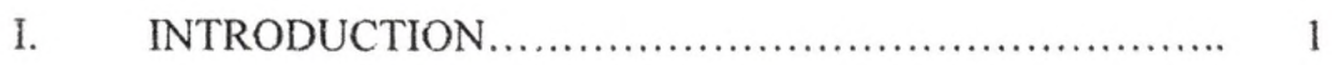

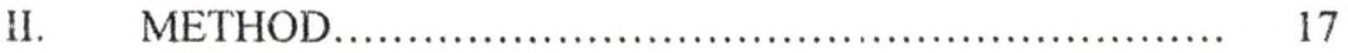

III. RESULTS........................................... 24

IV. DISCUSSION ....................................... 31

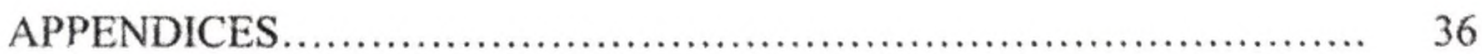

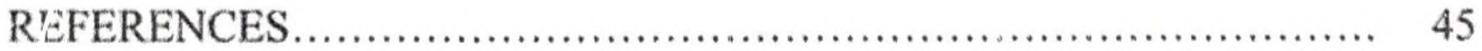




\section{LIST OF FIGURES}

Figure

Page

1. Flow Chart .......................................................... 23

2. Treatment Effects................................................... 26 


\section{LIST OF TABLES}

Table

1. Literature review for the effect of different types of stretching on DOMS....... 8

2. Literature review of stretching plus other methods of treating DOMS .........10

3. Literature review of warming-up with $s^{t}$ : ztcises and muscle performance....... 12

4. Literature review of injury, stretching, and DOMS ........................ 14

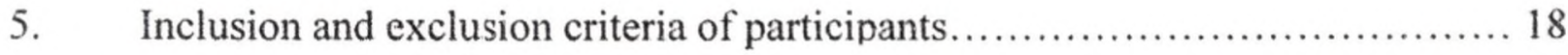

6. Descriptive Statistics..................................................... 24

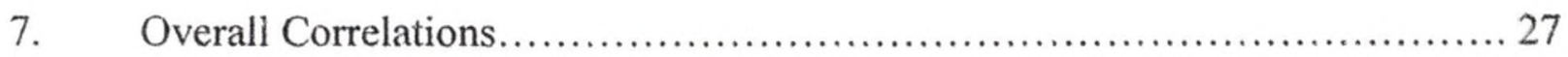

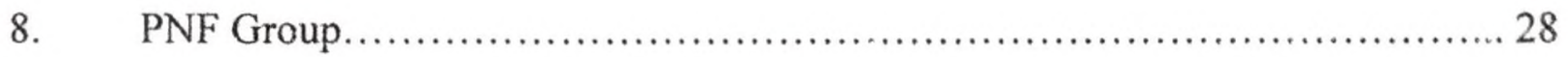

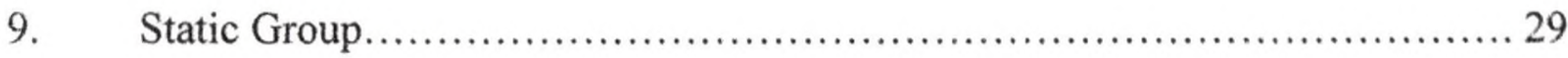

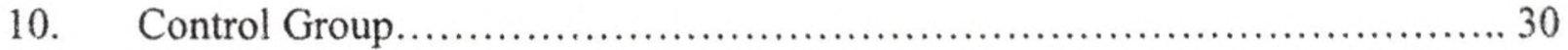




\section{ACKNOWLEDGMENTS}

First and foremost, I would like to thank God. Without God none of this would be possible.

I would like to thank the University of North Dakota for allowing me to attend this fine institution. It has been a wonderful experience attending school here, something I will never forget. The PXW faculty gave me a first class education. The faculty is always committed to he student, which makes things easy and comfortable.

I would like to thank Jamestown College for my undergraduate degree. The small class sizes, faculty, and football team was a big reason I was able to obtain my undergraduate degree.

I would like to thank Dr. James Whitehead for being a great advisor, mentor, and role model. You have done nothing but give since the beginning. You are a big reason why I am ieaving UND with a degree. Keep up the good work because it does not go unnoticed.

I would like to thank my family and friends for being so supportive. Many of you have helped me so much in so many ways. I owe a lot to most of you.

Finally, I would like to thank my parents (Daniel and Maria McGrath). If I have children, you have raised the bar high for me to exceed as a parent. Your countless love and guidance are beyond words. I love you both so much sidi am forever in your debt. 


\section{ABSTRACT}

Until recently, research suggested that post-exercise stretching may reduce delayed onset muscle soreness (DOMS) in those who exercise; however, newer research indicates that stretching has no effect on DOMS. However, it appears that the effect of proprioceptive neuromuscular facilitation (PNF) stretching on preventing DOMS has not been adequately studied. The primary purpose of the study was to research the effect of PNF stretching on DOMS. The secondary purpose was to evaluate if one's level of flexibility had a correlatior with high levels of DOMS. The study was a posttest-only control group design. Participants were randomly assigned into a stretching group (PNF, static, control) after performing a DOMS inducing exercise. Participants then rated their soreness level on a pain scale (range 1-6) 24 and 48 (plus or minus 2 hours) hours after the DOMS inducing exercise. Flexibility also was measured to see if the participants muscle range was correlated to DOMS. The main result showed that there was no difference between PNF stretching and reduced pain scores. Other results showed that there was a correlation between the 48 hour post-exercise pain score and pre-post flexibility change in the PNF stretch group $(p<.01)$, a correlation between the 48 hour post-exercise pain score and pre-exercise stretch score overall $(\mathrm{p}<.05)$, and a correlation between the 48 hour post-exercise pain score and the post-exercise stretch score overall $(p<.05)$. The results suggest that PNF stretches may have possibly placed a load on an already damaged muscle causing more strain on the trained muscle. Suggestions for future research include a prolonged study similar to this, assess ones DOMS level by 
using biochemical markers, or use of vibration platform training with a stretching protocol. 


\section{CHAPTER I}

\section{INTRODUCTION}

There is often nothing more satisfying for those who exercise than completing a hard, intense workout; however, there may be nothing more annoying than the pain and stiffness that may follow the workout. It is believed by some that stretching after exercising will reduce the amount of soreness they may feel (Bobbert, Hollander, \& Huijing (1986). There are many different types of stretches that individuals may perform to try to reduce muscle soreness.

Flexibility is one of the five major components of health-related fitness (Corbin \& Lindsey, 2005). Stretching is often the most neglected component of exercise (Hedrick, 1993). Proposed benefits of stretching include increasing muscular performance and an increased range of motion, reduction of injury, and stretching of tendons (Pollock et ail, 1998). Although these are great reasons for individuals to stretch, those who exercise often neglect flexibility and stretching. It may be that some people may not stretch because they believe that stretching is too time consuming and pointless (Hedrick, 1993). Others do not like the pulling and discomfort that occurs during stretching. In addition, stretching/flexibility are often not associated with exercise goals of most people (Hedrick, 1993). 
It has been suggested that a general stretching program that exercises the major muscle/tendon groups should be devcioped issing different types of stretching (Pollock et al., 1998). Generally, there are three major types of stretches: static, ballistic, and proprioceptive neuromuscular facilitation (PNF) (Pollock et al., 1998). All three types of stretches may be done actively (stretch agonist muscle with the antagonist muscle) or passively (assistance from other non-antagonist muscles, an assistant, or from an apparatus). PNF stretching is defined as alternating isometric contraction combined with passive stretching through a selected series of motions (McAtee, 2007). The key point when performing PNF stretching is to pre-contract the muscle being stretched. An example of PNF stretching may include an individual holding another person's leg perpendicular to the ground at which point he/she contacts the muscle for a short period of time.

Bailistic stretching involves repetitive bouncing motions where the muscle is rapidly stretched and immediately relaxed. It is important to know that ballistic stretching uses momentum to produce the stretch. There is concern that when one performs ballistic stretching, it may overstrain the muscle resulting in injury (Corbin \& Lindsey, 2005). Due to the possible muscular damage involved with ballistic stretching, some may not recommend that one performs ballistic stretching unless ballistic stretching is specific to the individuals exercise regimen (Curbin \& Lindsey, 2005).

Static stretches are done actively and passively. It is important to know that static stretches should be held for ten to thirty seconds (Pollock et al., 1998). About four repetitions per muscle group should be completed for a minimum of two to three days per 
week for sta'ic stretching (Pollock et al., 1998). Although this is a recommended amount. individuals may not do what is recornmended in order to suit their individual needs.

Pollock et al. (1998) suggested that it is not in the best interest for individuals to neglect stretching because doing so may be harmful to their bodies. The positive effects of stretching significantly outweigh the negative (Hume, Cheung, Maxwell, \& Weerapong, 2004). Flexibility is an important aspect of health related fitness, and stretching is often necessary to obtain flexibility. Regular stretching has traditionally been recommended tor several reasons because it is an important component in sport, health, and fitness (Corbin \& Lindsay, 2005).

Soreness after exercise is characterized into two different categories: acute muscle soreness and delayed onset muscular soreness (DOMS) (Kent, 1998). Acute muscle soreness is soreness that occurs immediatcly after or during training. This soreness is typicaliy due to poor blood flow to the trained area or local swelling/edema. Soreness felt by muscles hours/days after exercise is a phenomenon called DOMS. According to the Oxford Lictionary of Sports Science and Medicine, DOMS is muscular discomfort that develops one or two days after exercise has stopped. DOMS is generally considered to be an adult phenomenon, but some children also exhibit DOMS too (Plowman \& Smith, 2003). Muscle soreness is a very common problem that affects the physical and psychological performance of athietes and those who exercise (Bobbert, Hollander, and Huiging, 1986).

An individual can experience DOMS as a result of doing many different exercises: when the individual exercises at a much higher intensity than normally 
accustomed to, when a person exercises for a much longer duration than normally accustomed to, and when the type of specific muscle contraction is considerably different than accustomed to (e.g., concentric and eccentric) is when a person is likely to experience DOMS (McArdle, Katch, \& Katch, 2007). Activities that include eccentric contractions are most likely to induce DOMS (e.g., negative/eccentric bench press; Hakkenin et al., 1998). Furthermore, eccentric strength training is believed to be a very efficient way to strengthen one's muscles quickly (Higbie, Cureton, Warren, \& Prior, 1996). Treatment of DOMS consists of rest and use of anti-inflammatory drugs, such as aspirin (Rahnama, Rahmani-Nia, \& Ebrahim, 2005). Recommendations for reducing DOMS have included reducing eccentric contractions, training at a lower intensity, and performing post-training routines that include stretching (Kent, 1998).

DOMS is of concern to exercise experts because it affects athletic performance and exercise participation (Plowman \& Smith, 2003). The cause of DOMS has drawn significant research attention because of its importance. Two of the primary theories of DOMS are the mechanical trauma theory and the local ischemic theory (Plowman \& Smith, 2003). These theories are not identical; however, they share many similarities.

The mechanical trauma theory was conceptualized by Armstrong, Laughlin, Rome, and Taylor in 1983. This theory proposes to describe the mechanisms responsible for DOMS (Plowman \& Smith, 2003). This theory developed from a study of several laboratory rats that were tested running on incline and decline treadmills (Armstrong et a!., 1983). The treadmills were set to various speeds and slopes. VO2 levels and blood lactate measurements showed that metabolism during and post-exercise was higher in the rats who ran uphill. Those rats had to use more energy to run at an incline and their 
muscles became damaged. This muscle damage also resulted in measurements of DOMS. Plowman and Smith (2003) give a definitive physiological description of the mechanical trauma theory.

Plowman and Smith (2003) commented:

The mechanical trauma model suggests that the mechanical forces in the contractile or elastic tissue result in structural damage to the muscle fibers.

Damage to the sarcolemma of the cell leads to disruption in calcium homeostasis, which results in death $f$ the tissue. The presence of cellular debris and immune cells leads to swelling and inflammation, which is responsible for the sensation of DOMS (Plowman \& Smith, 2003, p.535).

The local ischemic theory was developed by Devries and Housh (1995). They suggested that exercise causes edema in the muscle tissue, which then increases the pressure in the muscle tissue. Due to the increase in muscle tissue pressure, blood flow is reduced to the muscle which causes pain and muscle constriction. The muscle constriction then becomes the primary factor of DOMS. The local ischemic theory was conceptualized by Devries and Housh (1995) who measured thresholds of neuromuscular fatigue in the muscies of the rectus femoris. Through the use of electromyographic fatigue threshold, it was discovered that the superficial muscles of the rectus femoris experienced more fatigue during exercise than the deep muscles (Deveries \& Haush. 1995).

It is pussible that both theories are valid (Plowman \& Smith. 2003). The local ischemic theory expiains that overtraining involving long duration and vigorous intensity 
activities leads to DOMS. The mechanical trauma model explains that DOMS takes place after activities that place significant automatic force on the muscle; specifically, eccentric contractions. Much of the research that supports the mechanical trauma theory has used eccentric exercise as a means of inducing DOMS. DOMS is produced by microscopic tears in the muscle (McArdle, Katch, \& Katch, 2007). These tears release intracellular substances that induce the inflammatory response. The local ischemic theory and the mechanical trauma theory both achieve DOMS this way; however, the theories use different exercise methods to achieve the (proposed) tears that result in DOMS.

One of the more popular concepts regarding DOMS is that it is caused by accumulation of lactic acid (Edington \& Edgerton, 1976). Research such as the mechanical trauma theory and the local ischemic theory, however, fail to support that lactic acid accumulation is the cause of DOMS (Cheung, K., Hume, P., \& Maxwell, L., 2003). More specifically, those who suffer from McArdle's syndrome and do not produce lactic acid suffer from DOMS too (Plowman \& Smith, 2003). McArdle's syndrome is a rapid onset of muscle fatigue, pain, and cramping during moderate and vigorous exercise (Lewis, Haller, Cook, \& Nunnally, 1985). This is from the inability to breakdown glucose, which is a very important source of energy stored in the muscle. Also, lactic acid has a half-life of 15-25 minutes and is removed from the muscle in about an hour. Due to the removal of lactic acid from the muscle, lactic acid cannot cause DOMS (Lewis, Haller, Cook, \& Nunnally, 1985).

Researchers have investigated whether stretching muscles post-exercise reduces levels of DOMS (Hebert \& de Noronha, 2009). At rest, muscle tissue damaged during exercise repairs itself and becomes stronger through hypertrophy in order to adapt to the 
workload and contractile forces being placed on the body. (Brooks, Fahey, \& Baldwin, 2005). It has been suggested that stretching can accelerate recovery of the muscles, which will reduce levels of DOMS (Bobbert, Hollander, \& Huijing, 1986).

The idea that stretching can reduce levels of DOMS is controversial. Some suggest that stretching can prevent DOMS after training (Bobbert, Hollander, \& Huijing, 1986); others hypothesize that stretching has little effect on the prevention of DOMS (Wessei \& Wan, 1994) based on anecdotal rather than scientific evidence (ACSM, 2000).

Perforining regular stretching exercises can greatly increase flexibility of the area being stretched (Smith \& Fryer, 2008). Doing a stretching routine post-exercise could be beneficial because it supports the local ischemic theory (Resiman, Walsh, \& Proske, 2005). Furthermore, stretching the muscle will lengthen it resulting in a speedy recovery time (Bobbert et al., 1986). Regardless of the theory of DOMS causation, different stretching techniques may have a role in reducing DOMS.

\section{Specific Studies on the Effect of Stretching on DOMS}

There is a substantial amount of research about the effect of stretching and DOMS. Traditionally, DOMS is measured by overtraining the muscle and having the participants rank their level of soreness after a period of time. As shown in Table 1 most of this research has included testing the effect of different types of stretches on DOMS. All of the studies in Table 1 involve the participants of each study engaging in static stretching and all of the studies are testing stretching as a mechanism to relief DOMS. Furthermore, the studies in Table 1 use a stretch protocol before or after training in efforts to relief DOMS. Results are mixed. 


\begin{tabular}{|c|c|c|c|c|}
\hline $\begin{array}{c}\text { Authors \& } \\
\text { year }\end{array}$ & $\begin{array}{c}\text { Types of } \\
\text { stretching }\end{array}$ & $\begin{array}{c}\text { DOMS related } \\
\text { variables }\end{array}$ & Procedure & Results \\
\hline $\begin{array}{l}\text { Bobbert, } \\
\text { Hollander, \& } \\
\text { Huijing } \\
\text { (1986) }\end{array}$ & $\begin{array}{l}\text { Static- } \\
\text { active }\end{array}$ & $\begin{array}{l}\text { Amount of } \\
\text { DOMS in } \\
\text { trained area }\end{array}$ & $\begin{array}{l}\text { Participants over trained the gastrocnemius } \\
\text { muscle. They then used static-active } \\
\text { stretches on one leg while the other leg was } \\
\text { the control. Participants then rated their } \\
\text { level of DOMS on each leg. }\end{array}$ & $\begin{array}{l}\text { The experimental leg showed } \\
\text { lower levels of DOMS } \\
\text { compared to the control leg } \\
\text { (positive effects). }\end{array}$ \\
\hline $\begin{array}{l}\text { Smith et al. } \\
\text { (1993) }\end{array}$ & $\begin{array}{l}\text { Ballistic } \\
\text { and Static- } \\
\text { active }\end{array}$ & $\begin{array}{l}\text { Amount of } \\
\text { DOMS on areas } \\
\text { stretched }\end{array}$ & $\begin{array}{l}\text { Participants were randomly divided into } \\
\text { two groups and performed three identical } \\
\text { sets of } 17 \text { stretches in various areas of the } \\
\text { body. Those who static stretched held their } \\
\text { stretched for } 60 \text { seconds. The ballistic } \\
\text { performed their stretch for } 60 \text { bounces per } \\
\text { minute. Participants then rated their } \\
\text { soreness level on a ten point scaie before } \\
\text { the stretching routine, } 24,48,72,96 \text {, and } \\
120 \text { hours after the stretching routine. } \\
\text { Participants just did the prescribed } \\
\text { stretches, no other exercise. }\end{array}$ & $\begin{array}{l}\text { Those who pirformed static- } \\
\text { active siretches had higher } \\
\text { levels of participants suffering } \\
\text { from DOMS compared to the } \\
\text { ballistic stretching groups. The } \\
\text { highest amount of DOMS } \\
\text { occurred after } 24 \text { hours } \\
\text { (positive effects). }\end{array}$ \\
\hline $\begin{array}{l}\text { Wessel \& Wan } \\
\text { (1994) }\end{array}$ & $\begin{array}{l}\text { Static- } \\
\text { active }\end{array}$ & $\begin{array}{l}\text { Amount of } \\
\text { DOMS in } \\
\text { trained area } \\
\text { post-exercise }\end{array}$ & $\begin{array}{l}\text { Soreness in knee flexor muscle was induced } \\
\text { with concentric or eccentric contractions. } \\
\text { Knee flexor muscles of expermental leg } \\
\text { were stretched before exercise in } \\
\text { experiment } 1 \text { and after exercise in } \\
\text { experiment } 2 \text {. Ten stretches were } \\
\text { performed, each of } 60 \text { seconds duration. } \\
\text { Muscle soreness measured } 12,24,36,48 \text {, } \\
60 \text {, and } 72 \text { hours after exercise on a } 100 \\
\text { point scale. }\end{array}$ & $\begin{array}{l}\text { The stretching routine } \\
\text { performed before or after } \\
\text { eccentric exercise did not } \\
\text { reduce DOMS (negative } \\
\text { effects). }\end{array}$ \\
\hline $\begin{array}{l}\text { Lund, } \\
\text { Vestergaard- } \\
\text { Poulsen, \& } \\
\text { Kanstrup } \\
\text { (1998) }\end{array}$ & $\begin{array}{l}\text { Static- } \\
\text { passive }\end{array}$ & $\begin{array}{l}\text { Amount of } \\
\text { DOMS felt by } \\
\text { the participants }\end{array}$ & $\begin{array}{l}\text { In the first experiment, participants } \\
\text { performed eccentric strenuous exercise with } \\
\text { the right quadriceps until exhaustion with } \\
\text { no stretching. In the second experiment, } \\
\text { participants again performed eccentric } \\
\text { strenuous exercise on the right quadriceps } \\
\text { until exhaustion. Following the exercise, } \\
\text { participants participated in the stretches for } \\
30 \text { seconds, with a } 30 \text { second pause } \\
\text { between sets, for } 3 \text { sets. }\end{array}$ & $\begin{array}{l}\text { Static-passive stretching did not } \\
\text { have any significant influence } \\
\text { on reducing DOMS in the } \\
\text { participants (negative effects). }\end{array}$ \\
\hline $\begin{array}{l}\text { Resiman et al. } \\
(2005)\end{array}$ & $\begin{array}{l}\text { Static- } \\
\text { passive }\end{array}$ & $\begin{array}{l}\text { Amount of } \\
\text { DOMS felt by } \\
\text { the participants }\end{array}$ & $\begin{array}{l}\text { Participants performed static-passive } \\
\text { stretches on one arm prior to eccentric } \\
\text { exercise. The other arm was the control. } \\
\text { Participants then performed elbow flexors } \\
\text { until extreme fatigue. Participants rated } \\
\text { DOMS and arm posture was measured. }\end{array}$ & $\begin{array}{l}\text { Pre-exercise stretching may } \\
\text { reduce DOMS and improve } \\
\text { posture of trained/stretched area } \\
\text { of the body (positive effects). }\end{array}$ \\
\hline $\begin{array}{l}\text { High, Howley, } \\
\text { \& Frands } \\
\text { (1989) }\end{array}$ & $\begin{array}{l}\text { Static } \\
\text { stretching } \\
\text { and'or } \\
\text { warm-tup }\end{array}$ & $\begin{array}{l}\text { Amount of } \\
\text { DOMS felt by } \\
\text { the participants }\end{array}$ & $\begin{array}{l}\text { Soreness in leg muscles induced with step } \\
\text { test. Before exercise. the stretching group } \\
\text { performed } 2 \text { quadriceps stretches each for } \\
60 \text { seconds. The warm-up group performed } \\
\text { an active warm-up. Then both groups did } \\
\text { both stretching and warm-up. The control } \\
\text { group did nothing. Muscle soreness was } \\
\text { measured } 24 \text { hours after the step test on 0-6 } \\
\text { point scale. }\end{array}$ & $\begin{array}{l}\text { Static stretching and/or warm- } \\
\text { up did not prevent DOMS } \\
\text { (negative effects). }\end{array}$ \\
\hline $\begin{array}{c}\text { Sady, } \\
\text { Wortman, \& } \\
\text { Blanke (1982) }\end{array}$ & $\begin{array}{l}\text { Ballistic } \\
\text { and static- } \\
\text { active }\end{array}$ & $\begin{array}{l}\text { Amount of } \\
\text { flexibility } \\
\text { achieved by the } \\
\text { participants. A } \\
\text { flexible muscle } \\
\text { may reduce } \\
\text { DOMS }\end{array}$ & $\begin{array}{l}\text { Participants were divided into } 4 \text { different } \\
\text { groups: control, static-active, balistic and } \\
\text { PNF. Baseline measurements were obtained } \\
\text { on } 2 \text { separate days prior to and following a } \\
\text { 3-day per week, } 6 \text {-week flexibility training } \\
\text { program. The amount of flexibility was } \\
\text { measured by each group over time. }\end{array}$ & $\begin{array}{l}\text { PNF stretching may be the } \\
\text { preferred stretching technique } \\
\text { for improving flexibility. This } \\
\text { may indicate that beeause PNF } \\
\text { streiching increases lexibility, } \\
\text { it is likely PNF strefching may } \\
\text { lower DOMS when compared } \\
\text { to the other types of stretches } \\
\text { done in the study. }\end{array}$ \\
\hline
\end{tabular}


Perusal of Table 1 reveals three studies which showed stretching reduced DOMS, while three other studies showed stretching did not reduce DOMS. In Table 1, all of the participants used a pain scale to rate their DOMS level. There are also mixed results about doing stretches before/after exercise or what type of stretches can reduce DOMS. One study measured flexibility (i.e. Sady et al, 1982) and was included in this section because it is believed by many that a flexible muscle recovers faster from training (e.g. Corbin \& Lindsey, 2005). Smith et al. (1993) identified a possible variable that induces DOMS by stretching alone. The participants in that study may not have normally accustomed to doing an extensive stretching routine. Their flexibiiity level may have induced DOMS because they are not used to doing that type of muscle contraction for a long period of time.

Pain tolerance may play a role in participants too. Each person has a different pain tolerance; for this reason, the results in Table 1 may have been skewed. Gender, age, race, occupation, and many other variables may also influence pain. Typically, men tolerate more pain than women, Caucasians tolerate more pain than Orientals and African-Americans, pain tolerance decreases with age, and those exposed to daily pain have more tolerance than those who do not (Woodrow, Friedman, Siegelaub, \& Collen, 1972). Pain tolerance may differ from each participant.

Apart from or in addition to stretching, other methods of reducing DOMS have also been tested. Drugs, massage, muscle treatments, ard many other tactics have been administered to participants to see if they reduce DOMS. The independent variables in Table 2 focus on non-stretch mechanisms that muy reduce DOMS. All of the studies in Table 2 test DOMS fe!t by the participants. The independent variable(s) (DOMS reducing 
mechanism) were introduced after the DOMS inducing exercise. The majority of the

tested variables showed that DOMS was not eased by using a non-stretch mechanism.

This research is included because in most cases the interventions also included stretching.

Table 2: Literature review of stretching plus other methods of treating DOMS

\begin{tabular}{|c|c|c|c|c|}
\hline Author \& year & Independent variable & $\begin{array}{c}\text { Dependent } \\
\text { variable }\end{array}$ & Procedure & Results \\
\hline $\begin{array}{c}\text { Rodenburg, } \\
\text { Steenbeek, \& } \\
\text { Schiereck (1994) }\end{array}$ & $\begin{array}{l}\text { Stretching, warm-up } \\
\text { and massage }\end{array}$ & $\begin{array}{l}\text { Amount of } \\
\text { DOMS felt by } \\
\text { the participant }\end{array}$ & $\begin{array}{l}\text { Participants were randomly } \\
\text { divided into experimental and } \\
\text { control groups. The experimental } \\
\text { group did a combination of warm- } \\
\text { up and stretching before eccentric } \\
\text { exercise. The experimental group } \\
\text { then received a massage after } \\
\text { exercise. The control group just } \\
\text { did the eccentric exercise. } \\
\text { Participants then ranked their } \\
\text { soreness on a scale. }\end{array}$ & $\begin{array}{l}\text { A combination of } \\
\text { warm-up and stretching } \\
\text { before eccentric } \\
\text { exercise and massage } \\
\text { after exercise, was } \\
\text { effective in reducing } \\
\text { severity of DOMS }\end{array}$ \\
\hline Gulick et al (1996) & $\begin{array}{l}\text { Anti-inflammatory } \\
\text { drug, high veiocity } \\
\text { concentric muscle } \\
\text { contractions on an } \\
\text { upper extremity } \\
\text { ergometer, ice massage, } \\
\text { 10-minute static } \\
\text { stretching, ointment, } \\
\text { and a placebo. }\end{array}$ & $\begin{array}{l}\text { Amount of } \\
\text { DOMS felt by } \\
\text { the participant } \\
\text { following the } \\
\text { training and } \\
\text { independent } \\
\text { variables }\end{array}$ & $\begin{array}{l}\text { Participants were randomly } \\
\text { assigned to a possible DOMS } \\
\text { reducing variable. Participants } \\
\text { then performed physical activity } \\
\text { that would induce DOMS. The } \\
\text { possible DOMS reducing variable } \\
\text { was administered and DOMS } \\
\text { level was rated by the participants } \\
\text { afterwarc. }\end{array}$ & $\begin{array}{l}\text { Only time was able to } \\
\text { lower DOMS in } \\
\text { participants. }\end{array}$ \\
\hline $\begin{array}{l}\text { Rahnama et al. } \\
\quad(2005)\end{array}$ & $\begin{array}{l}\text { Warm-up stretching } \\
\text { and ibuprofen }\end{array}$ & $\begin{array}{l}\text { Amount of } \\
\text { DOMS felt by } \\
\text { the participant } \\
\text { following } \\
\text { training and } \\
\text { independent } \\
\text { variables. }\end{array}$ & $\begin{array}{l}\text { Participants were divided into four } \\
\text { random groups. The Solmon four } \\
\text { group design was used. This } \\
\text { consisted of warm-up stietches, } \\
\text { ibuprofen, and a control. DOMS } \\
\text { levels were then recorded. } \\
\text { Participants then ranked their } \\
\text { muscle soreness. }\end{array}$ & $\begin{array}{l}\text { Doing a physical } \\
\text { activity warm-up with } \\
\text { or without ibuprofen } \\
\text { prevented DOMS. }\end{array}$ \\
\hline $\begin{array}{l}\text { Zainuddin,Newton, } \\
\text { Sacco, \& Nosaka } \\
\text { (2005) }\end{array}$ & Massage & $\begin{array}{l}\text { Amount of } \\
\text { DOMS felt by } \\
\text { the participant } \\
\text { following } \\
\text { training and the } \\
\text { independent } \\
\text { variablc. }\end{array}$ & $\begin{array}{l}\text { Participants performed } 10 \text { sets of } \\
6 \text { maximal eccentric actions of the } \\
\text { elbow flexors with each arm. One } \\
\text { arm received } 10 \text { minutes of } \\
\text { massage } 3 \text { hours after eccentric } \\
\text { exercise; the other arm received } \\
\text { no treatment. DOMS levels were } \\
\text { shortly measured after the } \\
\text { massage. }\end{array}$ & $\begin{array}{l}\text { Massage was effective } \\
\text { in alleviating DOMS } \\
\text { by approximately } 30 \% \\
\text { aid reducing swelling, } \\
\text { but it had no effect on } \\
\text { muscle function. }\end{array}$ \\
\hline Moraska (2007) & Massage & $\begin{array}{l}\text { Amount of } \\
\text { DOMS felt by } \\
\text { the participant } \\
\text { following } \\
\text { training, and the } \\
\text { independent } \\
\text { variable. }\end{array}$ & $\begin{array}{l}\text { Participants were offered a } 12-15 \\
\text { minute massage after running a } \\
\text { race. Participants were ranoumly } \\
\text { assigned to a student therapist } \\
\text { with either } 450,700 \text {, or } 950 \text { hours } \\
\text { of training in massage. A } 10 \text { point } \\
\text { muscle soreness questionnaire was } \\
\text { given to the participants before } \\
\text { and after the massage, and } 24 \text { and } \\
48 \text { hours post-race. }\end{array}$ & $\begin{array}{l}\text { The greater reduction } \\
\text { in muscle soreness was } \\
\text { achieved by therapists } \\
\text { with } 950 \text { hours of } \\
\text { training as opposed to } \\
\text { those with } 700 \text { or } 450 \\
\text { hours of massage } \\
\text { training. }\end{array}$ \\
\hline
\end{tabular}

The findings in Table 2 are important to this study because they show that most other variables aside from stretching are not necessary for the participant when trying to 
reduce DOMS. There are some data however that suggest gentle massage can reduce DOMS (Rodenburg et al., 1994). However, bias may have been introduced in the Moraska (2007) study because Moraska should not have advertised the level of training each masseuse had. Those participants who received massages from masseuses with the most training may have convinced themselves that their massages were more effective due to the higher level of masseuse training.

The results of the studies in Table 2 should be considered in DOMS research because if there is a variable that can prevent or reduce DOMS, stretching may become highly publicized as obsolete to DOMS prevention. Due to DOMS being developed from overtraining muscles (Kent, 1998), it is possible that stretching may cause DOMS because the load being placed on the muscles may be significant enough to fatigue muscles (Corbin \& Lindsey, 2005). If a person does not stretch regularly, they are likely to get DOMS from doing an extensive stretching routine because they are not normally accustomed to that type of specific muscle contraction.

Stretching and Muscle Performance

The level of muscular performance is important to consider when assessing DOMS. Stretching and warming-up before exercise may result in muscles that are capable of exerting more force while less likely to become injured (Corbin \& Lindsey, 2005). Again, all of the studies in Table 3 involve static stretching; however, the Worrell, Smith, and Winegardner (1994) study includes PNF and static stretching. The dependent variables in Table 3 test muscular efficiency through resistance training or VO2 maximum testing. Participants in these studies used a stretch protocol before exercising. 
The studies show that some stretching as part of warm-up may be beneficial to one's

muscle output. Table 3 is devoted to how warm-up impacts muscular performance.

Table 3: Literature review of warming-up with stretches and muscle performance

\begin{tabular}{|c|c|c|c|c|}
\hline Author \& year & $\begin{array}{c}\text { Independent } \\
\text { variable }\end{array}$ & $\begin{array}{c}\text { Dependent } \\
\text { variable }\end{array}$ & Procedural & Results \\
\hline $\begin{array}{l}\text { Worrell, Smith, } \\
\text { \& Winegardner } \\
\text { (1994) }\end{array}$ & $\begin{array}{l}\text { PNF and static- } \\
\text { active }\end{array}$ & $\begin{array}{l}\text { The amount of } \\
\text { muscular power } \\
\text { achieved by the } \\
\text { stretched area. }\end{array}$ & $\begin{array}{l}\text { Participants were assigned stretches to } \\
\text { the hamstring muscles. After the } \\
\text { participants were stretched, participants } \\
\text { were tested on hamstring strengh at } \\
\text { different degrees. }\end{array}$ & $\begin{array}{l}\text { PNF stretching was slightly } \\
\text { superior to static stretching in } \\
\text { hamstring performance; } \\
\text { however, both stretching } \\
\text { categories are beneficial to } \\
\text { hamstring performance. }\end{array}$ \\
\hline $\begin{array}{l}\text { Behm, Button, } \\
\text { \& Butt (2001) }\end{array}$ & Static-passive & $\begin{array}{l}\text { The amount of } \\
\text { muscular power } \\
\text { achieved by the } \\
\text { stretched area. }\end{array}$ & $\begin{array}{l}\text { Participants were divided into two } \\
\text { groups. The experimental group was } \\
\text { tested before and 5-10 minutes following } \\
\text { a } 20 \text { minute static stretching routine of } \\
\text { the quadriceps. The control group did no } \\
\text { stretching. Forces and twitches were } \\
\text { measured with sophisticated equipment. }\end{array}$ & $\begin{array}{l}\text { A regimen of prolonged, } \\
\text { static-passive stretching can } \\
\text { inhibit force of the knee } \\
\text { extensors. }\end{array}$ \\
\hline $\begin{array}{l}\text { Gleim, } \\
\text { Stachenteld, \& } \\
\text { Nicholas } \\
(1990)\end{array}$ & $\begin{array}{l}\text { Overall } \\
\text { flexibility } \\
\text { though static- } \\
\text { passive }\end{array}$ & VO2 maximum & $\begin{array}{l}\text { Participants were put though a series of } \\
\text { flexibility tests using static-passive } \\
\text { stretches. They were then to complete a } \\
\text { VO2 maximum or VO2 sub-maximum } \\
\text { test on a treadmill. }\end{array}$ & $\begin{array}{l}\text { Those who had more } \\
\text { flexibility had a higher VO2 } \\
\text { maximum than those who } \\
\text { had lower flexibility. }\end{array}$ \\
\hline
\end{tabular}

These studies should be taken into account when future studies on DOMS are planned. Behm et al. (2001) showed that doing a vigorous static stretching routine preexercise can inhibit maximal muscle output. Maximal muscular power output should be desired by an individual performing exercise; thus, doing an extensive stretching routine before training significantly increases the chances of the participants not achieving maximal muscle output, especially when one is unaccustomed to doing so. Muscles may become fatigued from the stretching routine and/or muscle tension at the joints may not be adequate resulting in poor muscle output. The results in Table 3 show that having participants stretch vigorously prior to exercising is questionable. Moderate stretching and warming-up one's muscle temperature is a better alternative specifically because there will be some muscle tension at the joints which will help muscle output (Behm et 1., 2001). 
A review about the effects of stretching a athletic performance was conducted by Ian Shrier (2004). This review examined 72 anticles that were related to the topic of the review. Shrier concluded that an acute bout of pre-exercise stretching does not improve force or jump height. Regular pre-exercise stretching improves force, jump height, and speed, although there is no evidence that irnproves running efficiency.

\section{Stretching and Injury}

Wher a person overtrains, sufficient rest time may not be allowed for the body to recover from the stress exercise ings. These exercised muscles are very fatigued and need to recover. Overtraining is defined as training at work level beyond physical tolerance limits so that the body is unable to recover completely during rest periods (Kent, 1998). A muscle thit suffers from DOMS is more likely to become injured because the tissue is still damaged (Udani, Singh, Singh, \& Sandoval, 2009). The independent variables in Table 4 examine if stretching reduces injury. Injury rates were recorded in each study; however, each study records their injury rates differentiy. For example, in the Ekstrand, Gillquist, and Liljedah (1983) study, injury rates are recorded by comparing a group that participated in a stretch intervention compared to a group that did not participate in the stretch intervention. This study differs from the Hartig and Henderson (1999) study. Here, the overall number of injuries was recorded. Results do show that stretching can be beneficial in reducing injury while training. Table 4 summarizes studies that evaluate stretching, DOMS, and injury together. 
Table 4: Literature review of injury, stretching, and DOMS

\begin{tabular}{|c|c|c|c|c|}
\hline $\begin{array}{c}\text { Author \& } \\
\text { year }\end{array}$ & $\begin{array}{c}\text { Independent } \\
\text { variable }\end{array}$ & $\begin{array}{l}\text { Dependent } \\
\text { variable }\end{array}$ & Procedural & Results \\
\hline $\begin{array}{l}\text { Ekstrand, } \\
\text { Giliquist, \& } \\
\text { Liljedah } \\
\text { (1983) }\end{array}$ & $\begin{array}{l}\text { Intervention on } \\
\text { hov, iv prevent } \\
\text { injury }\end{array}$ & $\begin{array}{l}\text { Amount of } \\
\text { injuries } \\
\text { between the } \\
\text { two groups }\end{array}$ & $\begin{array}{l}\text { Half of the teams received an } \\
\text { intervention on how to prevent injury. } \\
\text { The intervention included various topics } \\
\text { including how stretching plays a role in } \\
\text { injury prevention. The other group did } \\
\text { not receive the intervention. Injury } \\
\text { amount was then recorded between the } \\
\text { two groups. }\end{array}$ & $\begin{array}{l}\text { Seventy-five per cent fewer injuries } \\
\text { in the intervention group occurred } \\
\text { in comparison to the control group. }\end{array}$ \\
\hline $\begin{array}{l}\text { Hartig \& } \\
\text { Henderson } \\
\text { (1999) }\end{array}$ & $\begin{array}{l}\text { Stretching } \\
\text { routine prior to } \\
\text { physical training } \\
\text { and hamstring } \\
\text { flexibility }\end{array}$ & $\begin{array}{l}\text { Nuniber of } \\
\text { injuries }\end{array}$ & $\begin{array}{l}\text { Two different army companies going } \\
\text { through basic training at the same time } \\
\text { were used. Hamstring fiexibility was } \\
\text { checked at the beginning and at the end } \\
\text { of the } 13 \text {-week infantry basic training } \\
\text { course. The control company proceeded } \\
\text { through normal training. The } \\
\text { intervention company followed the same } \\
\text { program but added three hamstring } \\
\text { stretches to the routine. Lower extremity } \\
\text { over use injury rates were recorded. }\end{array}$ & $\begin{array}{l}\text { Hainstring fexibility increased } \\
\text { significantly in intervention group } \\
\text { compared with the control group. } \\
\text { The number of injuries was also } \\
\text { significantly lower in the } \\
\text { intervention group. Forty-three } \\
\text { injuries occurred in the control } \\
\text { group for an incidence rate of } \\
29.1 \% \text {, compared with the } 25 \\
\text { injurie: in the intervention group } \\
\text { for an incidence rate of } 17 \% \text {. }\end{array}$ \\
\hline $\begin{array}{l}\text { Pope, } \\
\text { Herbert, } \\
\text { Kirwan, } \\
\text { \&Grahain } \\
(2000)\end{array}$ & $\begin{array}{l}\text { Static stretching } \\
\text { before exercise }\end{array}$ & $\begin{array}{l}\text { injury levels } \\
\text { on } \\
\text { participants }\end{array}$ & $\begin{array}{l}1538 \text { male army recruits were randomly } \\
\text { assigned to stretching groups and control } \\
\text { groups. Over the } 12 \text { weeks of training, } \\
\text { both groups did an active warm-up. } \\
\text { After the active warm-up one group } \\
\text { performed a static stretching routine on } \\
\text { the lower extremities and one did not. }\end{array}$ & $\begin{array}{l}\text { There were } 158 \text { injuries in the } \\
\text { stretch group and } 175 \text { in the control } \\
\text { group. Static stretching before } \\
\text { training did not lower injury. }\end{array}$ \\
\hline
\end{tabular}

The studies on injury prevention through stretching in Table 4 indicate that stretching may play a role in injury reduction. Stretching a muscle immediately following training may not immediately reduce DOMS; however, a continually stretched, flexible muscle is less likely to be injured and may suffer less DOMS.

Overall, the studies in table 4 showed that stretching can have an effect on DOMS, muscle efficiency and injury. Researchers have shown that pre-exercise or postexercise stretching alone may or may not reduce DOMS (Bobbet et al., 1986; High et al., 1989; Lund et al., 1998; Resiman et al., 2005; Sady et al., 1982; Smith et al., 1993; Wessel \& Wan, 1994;), studies that measure DOMS without a stretch protocol (Gulick et al., 1996; Moraska, 2007), that stretching before exercise may lower muscle efficiency (Behm, et al., 2001), and that stretching before and/or after reduces frequency of injury 
(Edstrand et al., 1983; Hartig \& Henderson, 1999). There is little research concerning PNF stretching. The majority of stretches that were administered to the participants was static-active/static-passive stretching.

Two recentiy published reviews concerning whether stretching after exercise has an influence on reducing DOMS report mixed results (Hebert \& de Noronha, 2009; Hume et al., 2004). Hebert and de Noronha (2009) summarized 14 different studies and concluded that there is no need to further research the effects of stretching after exercise on DOMS due to the studies included in their review. They based their conclusions on the research that has shown that stretching has little or no effect of the reduction of DOMS. Another review as done by Hume et al. (2004) on treatment strategies affecting DOMS looking at 25 different studies showed that there was no research on the effects of other types of stretching (e.g. ballistic, PNF, and dynamic stretching) on muscle soreness and the severity of mus:le damage (Hume et al., 2004). A person may be confident saying static stretching techniques have little effect on reducing DOMS; however, there is little research concerning PNF stretching and its capability of lowering DOMS. Also, there is little research that investigates if level of flexibility plays a factor on DOMS if a person stretches.

\section{Summary}

Since there is little research concerning the effects of PNF stretching or flexibility on DOMS, further study of the topic needs attention. The majority of stretches that were administered to the participants in the literature were static-active/static-passive stretching. This lack of rescarch leads to the question, if a person is stretching to reduce DOMS, would PNF stretching be effective in lowering DOMS in individuals post- 
exercise compared to static stretching or no stretching? Also, does a person's flexibility level indicate likelihood of DOMS after stretching? It is hypothesized that participants twho engage in PNF stretching and those who have good flexibility will have a lower amount of DOMS. Participants who engage in static stretching post-exercise and those who are less flexible will have high levels of DOMS. The purpose of this study is to examine the premise that stretching, or at leust some types of stretching, is effective in reducing soreness of muscles. 


\section{CHAPTER II}

\section{METHOD}

This study investigated whether stretching after unaccustomed eccentric exercise could prevent delayed onset muscle soreness (DOMS). While previous research has shown little effect on post-exercise stretching on DOMS, the effects of PNF stretching on DOMS had not been tested. Therefore, this study was designed to specifically investigate whether post-exercise PNF stretching could limit or reduce DOMS.

\section{Design}

This study employed a posttest-only control group design (Campbell and Stanley, 1963) to study the effects of PNF, static, and no stretch (control group) on DOMS. In this randomized-groups design, the post-exercise participants were randomly assigned to one of three groups: PNF, static, or control. The dependent variable was the DOMS scores reported by each participant at 24 hours and 48 hours post-exercise (independent variables).

\section{Participants}

A convenience sample of 57 participants volunteered for this study. Participants were recruited as volunteers out of various physical education, exercise science, and wellness (PXW) classrooms. Participants were screened on age, history of injury, age, gender, level of training, level of performance, and size. Thomas, Nelson, and Silverman (2005) suggest using various inclusion and exclusion criteria because it helps target 
participants that would best suit the study. Table 5 discusses the inclusion and exclusion

criteria for participants who were involved in this study. The design of the study was a

posttest-only control group design.

Table 5: Inclusion and exclusion criteria of participants

\begin{tabular}{|c|c|c|c|}
\hline Participants & $\begin{array}{l}\text { Inclusion } \\
\text { Criteria }\end{array}$ & Exclusion Criteria & Why \\
\hline Age & $\begin{array}{l}\text { Must be } 18 \text { years } \\
\text { of age or older }\end{array}$ & $\begin{array}{c}\text { Below } 18 \text { years of } \\
\text { age }\end{array}$ & $\begin{array}{l}\text { Parental consent is not } \\
\text { necessary because } \\
\text { participants are adults. }\end{array}$ \\
\hline Gender & Males or females & None & N/A \\
\hline $\begin{array}{l}\text { Level of } \\
\text { Training }\end{array}$ & $\begin{array}{l}\text { Preference will be } \\
\text { given to those } \\
\text { who are somewhat } \\
\text { physically un- } \\
\text { trained }\end{array}$ & None & $\begin{array}{l}\text { When a participart is } \\
\text { untrained, they more likely to } \\
\text { suffer from DOMS because } \\
\text { they are not normally } \\
\text { accustomed to exercising } \\
\text { with high intensity }\end{array}$ \\
\hline $\begin{array}{c}\text { Level of } \\
\text { Performance }\end{array}$ & $\begin{array}{l}\text { Those who are } \\
\text { able to complete } \\
\text { all tasks that the } \\
\text { study demands }\end{array}$ & $\begin{array}{l}\text { Those who cannot } \\
\text { complete all tasks } \\
\text { that the study } \\
\text { demands }\end{array}$ & $\begin{array}{l}\text { Participants must complete } \\
\text { all tasks or they would not } \\
\text { valid participants }\end{array}$ \\
\hline $\begin{array}{l}\text { History of } \\
\text { Injury }\end{array}$ & None & $\begin{array}{l}\text { Those who have not } \\
\text { been cleared by a } \\
\text { doctor, therapist, or } \\
\text { trainer to exercise } \\
\text { area being tested }\end{array}$ & $\begin{array}{l}\text { Having a prior catastrophic } \\
\text { injury in the trained area may } \\
\text { result in an increased risk of } \\
\text { injury and/or may confuse } \\
\text { pain in the previously injured } \\
\text { area with DOMS }\end{array}$ \\
\hline Par-Q & $\begin{array}{l}\text { Answering "No" } \\
\text { to all questions }\end{array}$ & $\begin{array}{l}\text { Answering "Yes" to } \\
\text { one or more of the } \\
\text { questions }\end{array}$ & $\begin{array}{l}\text { Answering "Yes" may result } \\
\text { in a health complication of } \\
\text { the participant, which would } \\
\text { not make them eligible to } \\
\text { participate in the study }\end{array}$ \\
\hline $\begin{array}{l}\text { Consent } \\
\text { Form }\end{array}$ & $\begin{array}{l}\text { Completing } \\
\text { consent form }\end{array}$ & $\begin{array}{l}\text { Not completing } \\
\text { consent form }\end{array}$ & $\begin{array}{l}\text { Participants who complete } \\
\text { the consent form understand } \\
\text { the study; understand their } \\
\text { role in the study, and } \\
\text { possible risks involved in the } \\
\text { study }\end{array}$ \\
\hline
\end{tabular}


Those who were interested provided their name, e-mail, and phone number to the principal investigator after he explained the study. Those on the list were called by the researcher to set up a time for data collection. An exclusion and inclusion criterion was enforced at the beginning of the study.

\section{Measures/Instrume.iation}

Muscle Soreness

DOMS was assessed using the High et al. (1989) soreness scale (see Appendix A) (High et al., 1989, p. 359). The scale was chosen because due to the simplicity of the questionnaire. The scale asks participants to rank their level of soreness in a 1-6 point scale ranging from "absence of soreness" to "most extreme pain possible from soreness" (High et al., 1989).

Hamstring and lower back flexibility were measured using a standard sit and reach measurement box because a sit and reach test is the most common way to assess one's level of flexibility. Participants positioned themselves at the sit and reach box and reached forward and held the stretch while keeping their legs straight. Once they had reached forward as far as possible, the researcher recorded their score in centimeters.

\section{Procedures}

\section{Screening and Preliminary Organization}

Approval to conduct this study was granted by the IRB of the University of North Dakota (see Appendix D). After participant recruitment took place, specific times were arranged between each participant and the researcher to conduct the study so participant attendance was maximized. Participants then completed a standard consent form (see Appendix B). After completing the consent form, a PAR-Q was also given to participants 
to assess their overall health (see Appendix C). If the participant passed the PAR-Q, they were then evaluated by the inclusion and exclusion criteria. Finally, the screened participant was given verbal information about the study at the Wellness Center before performing the study.

DOMS Inducing Exercise \& Stretch Protocol

To prevent anticipation bias, the researcher did not identify what type of stretch the participant would be doing. For a warm-up, the participant did 5-10 minutes of easy jogging until they felt that they were ready to perform exercise. Participants then performed a sit and reach test and data were recorded.

The participant then performed his/her DOMS inducing exercise on the Leg Curl SP 5100 weight machine. Approximate number of repetitions was between eight and twelve. The participants concentrically contracted their hamstring muscles in a controlled movement and eccentrically contracted their muscles for 5 seconds per rep. The participant was asked to complete each exercise until they reached voluntary or muscular failure. Muscular failure is defined as when the participants are physically incapable of completing another repetition because their muscles are too fatigued. Voluntary failure is defined as when the participant feels that they are un-able or not willing to perform any more repetitions.

\section{Group Allocation}

Participants were randomly assigned to one of three groups: PNF stretch, static stretch, and control group. This was done by drawing a group allocation out of a hat before they participated in the study. 
After the DOMS-inducing leg curls, the participants were guided through the stretch protocols that they had been randomly assigned to. In the static group, participants sat on the floor with their legs apart. The participant then reached toward one foot with both hands while the researcher pushed on their back. When optimal stretch occurred, the stretch was held for ten seconds with four seconds rest for two sets on both legs.

The PNF stretch was performed on the hamstring. The participant was supine on the floor and the researcher elevated one leg on the researcher's shoulder while keeping the other leg straight. The leg was then further elevated while being kept straight and was contracted for five seconds, held for five seconds, and relaxed for four seconds. The participant did this two times with one leg and the same routine was performed on the other leg.

Those who were randomized to the control group performed no stretches. These participants were asked to relax for a moment. After the participant completed their stretches, another sit and reach test was conducted. The protocol for the post-exercise sitand-reach test was the same as the earlier sit-and-reach test.

\section{DOMS Questionnaire Administration}

Participants were again reminded that they must complete the questionnaire within the time constraints. Specified time periods between $22-26$ hours and $46-50$ hours post-exercise. Exact time specifications were given to the participant to remind them when to record their responses. They were also told not to do any type of physical activity or stretches on the region of the body that had been tidinu (munsumgs). This may affect the level of DOMS. Participants then compieted the pain questionnaire 
approximately 24 hours (plus or minus two hours) post-exercise and another 48 hours (plus or minus two hours) post exercise via e-mail. When the participant completed the pain questionnaires, he/she had completed the study. Figure ! illustrates the participant's involvement during their time at the UND Wellness Center.

Analysis

The main hypothesis in this study was that DOMS would be reduced by postexercise stretching. This was tested using analysis of variance. Specifically, a $3 \times 2$ (treatment group $\mathrm{x}$ time) mixed ANOVA was computed with scores on the pain scale as the dependent variable. Where it was necessary, post hoc testing using the Holm-Sidak method was conducted.

The secondary hypothesis in this study is that flexibility was associated with levels of DOMS was tested using Pearson correlation analysis. 
Figure 1: Flow Chart

Consent Form and PAR-Q

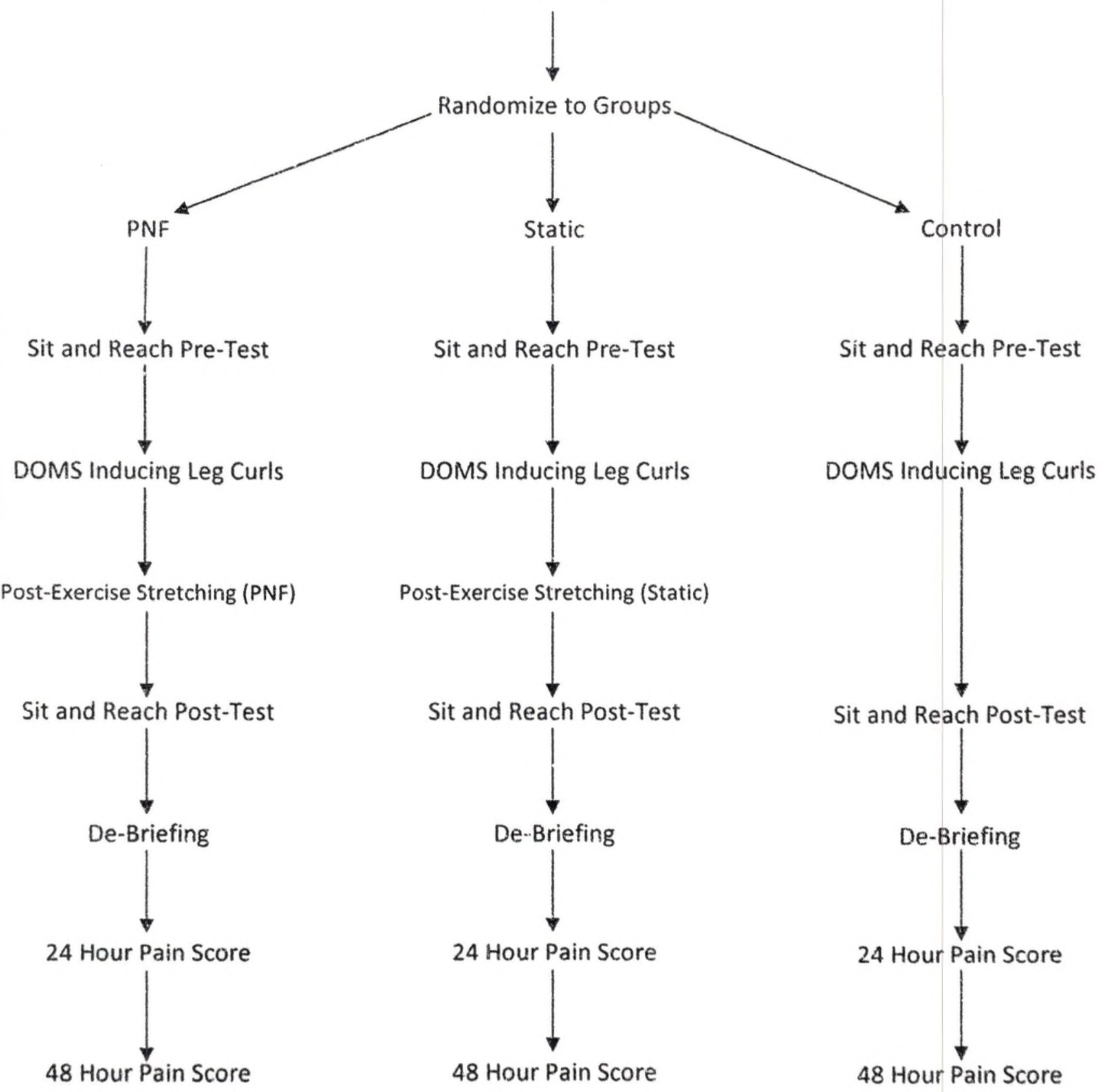




\section{CHAPTER III \\ RESULTS}

This study investigated whether stretching after unaccustomed eccentric exercise could prevent delayed onset muscle soreness (DOMS). While previous research has shown little effect on post-exercise stretching on DOMS, a specific type of stretching (PNF) had not been tested. Therefore, this study was designed to specifically investigate whether post-exercise PNF stretching could limit or reduce DOMS.

The descriptive statistics of the individual groups, and the sample overall, are presented in Table 6 below:

Table 6: Descriptive Statistics

\begin{tabular}{|c|c|c|c|c|c|c|c|c|}
\hline & \multicolumn{2}{|c|}{ Overall $(\mathrm{N}=57)$} & \multicolumn{2}{|c|}{ PNF $(n=19)$} & \multicolumn{2}{|c|}{ Static $(n=20)$} & \multicolumn{2}{|c|}{ Control $(n=18)$} \\
\hline & $m$ & $S D$ & $m$ & $S D$ & $m$ & $S D$ & $m$ & $S D$ \\
\hline Height (inches) & 68.49 & 3.50 & 68.37 & 2.69 & 70.00 & 3.88 & 66.94 & 3.28 \\
\hline Weight (lbs.) & 165.68 & 28.91 & 158.95 & 22.94 & 180.50 & 34.02 & 156.33 & 22.37 \\
\hline $\begin{array}{l}\text { Pre-exercise } \\
\text { stretch score } \\
(\mathrm{cm})\end{array}$ & 6.33 & 9.75 & 5.21 & 10.21 & 6.00 & 9.70 & 7.89 & 9.68 \\
\hline $\begin{array}{l}\text { Post-exercise } \\
\text { stretch score } \\
(\mathrm{cm})\end{array}$ & 7.91 & 9.71 & 6.26 & 10.26 & 8.50 & 9.74 & 9.00 & 9.41 \\
\hline $\begin{array}{l}24 \text { hour post- } \\
\text { exercise pain } \\
\text { score }\end{array}$ & 2.14 & .93 & & .78 & 2.25 & 1.07 & 1.94 & .93 \\
\hline
\end{tabular}


Table 6 cont.

\begin{tabular}{|l|lr|rr|rr|rr|}
\hline & \multicolumn{2}{|l|}{ Overall $(\mathrm{N}=57)$} & \multicolumn{2}{|c|}{ PNF $(\mathrm{n}=19)$} & \multicolumn{2}{|c|}{ Static $(\mathrm{n}=20)$} & \multicolumn{2}{|c|}{ Control $(\mathrm{n}=18)$} \\
& $m$ & $S D$ & $m$ & $S D$ & $m$ & $S D$ & $m$ & $S D$ \\
\hline $\begin{array}{l}48 \text { hour post- } \\
\text { exercise pain } \\
\text { score }\end{array}$ & 1.79 & .99 & 1.63 & 1.01 & 2.00 & 1.07 & 1.72 & .89 \\
\hline $\begin{array}{l}\text { Pre-Post } \\
\text { flexibility } \\
\text { change }(\mathrm{cm})\end{array}$ & 1.57 & 1.77 & 1.05 & 1.47 & 2.50 & 1.35 & 1.11 & 2.11 \\
\hline $\begin{array}{l}24 \text { to } 48 \text { hour } \\
\text { pain score } \\
\text { change }\end{array}$ & .35 & .89 & .57 & .90 & .25 & .96 & .22 & .80 \\
\hline
\end{tabular}

The primary focus of this study was the issue of whether post-exercise PNF stretching could prevent DOMS compared to post-exercise static stretching, or to no stretching. A $3 \times 2$ (group $\times$ time) mixed ANOVA with pain measures taken at 24 and 48 hours post-exercise was used to test this hypothesis. The results of this analysis showed no main effect for stretching type $(F[2,54]=.86, p=\mathrm{NS})$, or interaction between group and time $(F[2,54]=.93, p=\mathrm{NS})$. However, there was an effect for time $(F[1,54]=$ $8.67, p<.01$ ). Post hoc testing (Holm-Sidak method) showed that DOMS pain significantly decreased $(p<.05)$ from 24 to 48 hours post-exercise for the PNF and control groups, but not for the staric stretch group. This data set is presented in Figure 1. 


\section{Treatment Effects}

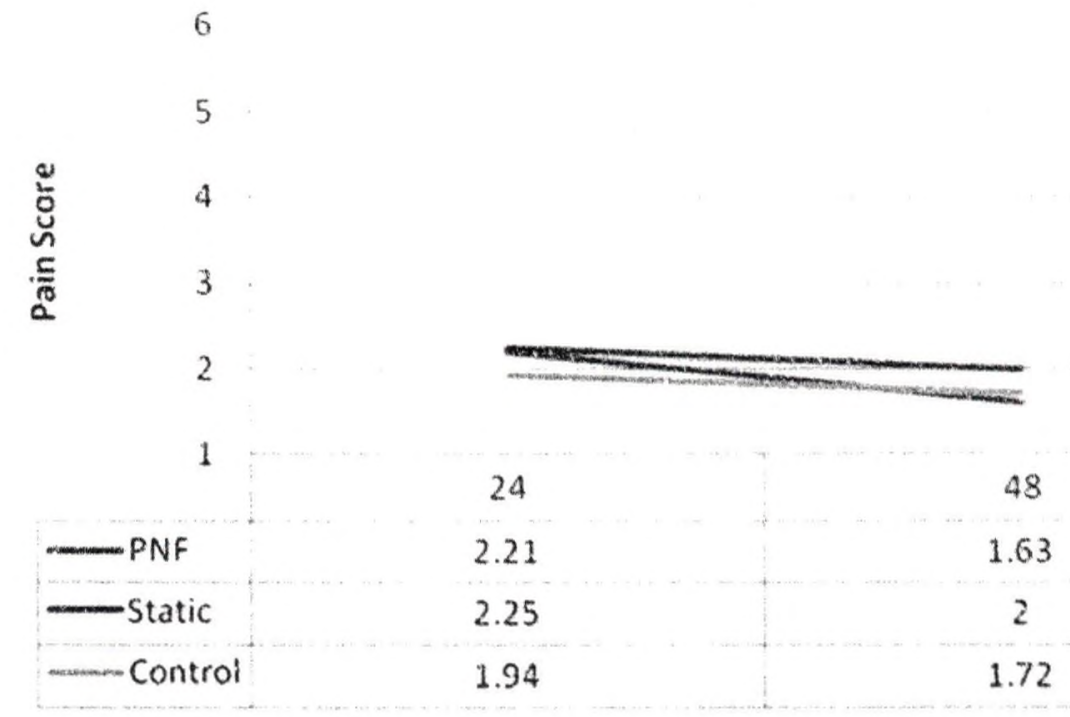

(Correlations for each type of stretch are listed in tables 7-10).

Tables 7-10 examine the correlations between the variables tested in Table 7.

There was a strong correlation between the pre and post-exercise stretch scores and the 48 hour pain score. This may indicate that the participant's flexibility score may have an effect on their level of DOMS. In Table 8 (PNF group), a correlation between the participant's 48 hour pain score and the Pre-Post flexibility change is identified. Due the level of strain put on the muscles during a PNF stretch, a trained muscle may become more damaged after performing PNF stretching. This may especially be the case if an individual is not flexible or if the individual is not normally accustomed to PNF stretching. 
Table 7: Overall Correlations $(\mathrm{N}=57)$

\begin{tabular}{|c|c|c|c|c|c|c|}
\hline & $\begin{array}{c}\text { Pre-- } \\
\text { exercise } \\
\text { stretch } \\
\text { score }\end{array}$ & $\begin{array}{l}\text { Post - } \\
\text { exercise } \\
\text { stretch } \\
\text { Score }\end{array}$ & $\begin{array}{l}24 \text { hour } \\
\text { post- } \\
\text { exercise } \\
\text { pain } \\
\text { score }\end{array}$ & $\begin{array}{l}48 \text { hour } \\
\text { post- } \\
\text { exercise } \\
\text { pain } \\
\text { score }\end{array}$ & $\begin{array}{l}\text { Pre-Post } \\
\text { flexibility } \\
\text { change }\end{array}$ & $\begin{array}{l}24 \text { to } 48 \\
\text { hour } \\
\text { pain } \\
\text { score } \\
\text { change }\end{array}$ \\
\hline $\begin{array}{l}\text { Pre-exercise } \\
\text { stretch score }\end{array}$ & - & $\mathrm{r}=.98 * * * *$ & $r=.07$ & $r=.29^{*}$ & $r=-11$ & $\mathrm{r}=-.24$ \\
\hline $\begin{array}{l}\text { Post-exercise } \\
\text { stretch score }\end{array}$ & & - & $\mathrm{r}=.07$ & $r=.33^{*}$ & $r=.06$ & $r=-.29$ \\
\hline $\begin{array}{l}24 \text { hour post- } \\
\text { exercise } \\
\text { pain score }\end{array}$ & & & - & $r=.57$ & $\mathrm{r}=.00$ & $r=.40$ \\
\hline $\begin{array}{l}48 \text { hour post- } \\
\text { exercise } \\
\text { pain score }\end{array}$ & & & & - & $r=.20$ & $r=.51$ \\
\hline $\begin{array}{l}\text { Pre-Post flexibility } \\
\text { change }\end{array}$ & & & & & - & $r=.23$ \\
\hline $\begin{array}{l}24 \text { to } 48 \text { hour } \\
\text { pain score change }\end{array}$ & & & & & & - \\
\hline
\end{tabular}

Key

PC: Pearson Correlation

${ }^{*} \mathrm{p}<.05$

${ }^{* *} \mathrm{p}<.01$

$* 2 * \mathrm{p}<.005$

$* * * * ;<<, 001$ 
Table 8: PNF Group ( $n=19)$

\begin{tabular}{|c|c|c|c|c|c|c|}
\hline & $\begin{array}{l}\text { Pre- } \\
\text { exercise } \\
\text { stretch } \\
\text { score } \\
\end{array}$ & $\begin{array}{c}\text { Post - } \\
\text { exercise } \\
\text { stretch } \\
\text { Score }\end{array}$ & $\begin{array}{c}24 \text { hour } \\
\text { post- } \\
\text { exercise } \\
\text { pain score }\end{array}$ & $\begin{array}{c}48 \text { hour } \\
\text { post- } \\
\text { exercise } \\
\text { pain score }\end{array}$ & $\begin{array}{l}\text { Pre-Post } \\
\text { flexibility } \\
\text { change }\end{array}$ & $\begin{array}{c}24 \text { to } 48 \\
\text { hour pain } \\
\text { score } \\
\text { change }\end{array}$ \\
\hline $\begin{array}{l}\text { Pre-exercise } \\
\text { stretch score }\end{array}$ & - & $r=.99^{* * * *}$ & $r=.08$ & $r=.25$ & $r=-.04$ & $r=-21$ \\
\hline $\begin{array}{l}\text { Post-exercise } \\
\text { stretch score }\end{array}$ & & - & $\mathrm{r}=.13$ & $r=.34$ & $\mathrm{r}=.10$ & $r=.27$ \\
\hline $\begin{array}{l}24 \text { hour post- } \\
\text { exercise pain } \\
\text { score }\end{array}$ & & & - & $r=.52$ & $r=.32$ & $\mathrm{r}=.28$ \\
\hline $\begin{array}{l}48 \text { hour post- } \\
\text { exercise pain } \\
\text { score }\end{array}$ & & & & - & $r=.61^{* *}$ & $r=.66$ \\
\hline $\begin{array}{l}\text { Pre-Post } \\
\text { flexibility } \\
\text { change }\end{array}$ & & & & & - & $r=-.40$ \\
\hline $\begin{array}{l}24 \text { to } 48 \text { hour } \\
\text { pain score change }\end{array}$ & & & & & & - \\
\hline
\end{tabular}

$\underline{\text { Key }}$

PC: Pearson Correiation

${ }^{*} \mathrm{p}<.05$

${ }^{* *} \mathrm{p}<0.01$

***p $<005$

***** $<<.001$ 
Table 9: Static Group $(n=20)$

\begin{tabular}{|c|c|c|c|c|c|c|}
\hline & $\begin{array}{l}\text { Pre- } \\
\text { exercise } \\
\text { stretch } \\
\text { score }\end{array}$ & $\begin{array}{l}\text { Post - } \\
\text { exercise } \\
\text { stretch } \\
\text { Score }\end{array}$ & $\begin{array}{l}24 \text { hour } \\
\text { post- } \\
\text { exercise } \\
\text { pain } \\
\text { score }\end{array}$ & $\begin{array}{l}48 \text { hour } \\
\text { post- } \\
\text { exercise } \\
\text { pain } \\
\text { score }\end{array}$ & $\begin{array}{l}\text { Pre-Post } \\
\text { flexibility } \\
\text { change }\end{array}$ & $\begin{array}{l}24 \text { to } 48 \\
\text { hour pain } \\
\text { score } \\
\text { change }\end{array}$ \\
\hline $\begin{array}{l}\text { Pre-exercise } \\
\text { stretch score }\end{array}$ & - & $\mathrm{r}=.99 * * * *$ & $r=.25$ & $r=.38$ & $r=-.04$ & $r=-.14$ \\
\hline $\begin{array}{l}\text { Post-exercise } \\
\text { stretch score }\end{array}$ & & - & $r=17$ & $r=.33$ & $r=.09$ & $r=-.18$ \\
\hline $\begin{array}{l}24 \text { hour post- } \\
\text { exercise pain } \\
\text { score }\end{array}$ & & & - & $\mathrm{r}=.59^{* *}$ & $r=-59 * *$ & $r=.44$ \\
\hline $\begin{array}{l}48 \text { hour post- } \\
\text { exercise pain } \\
\text { score }\end{array}$ & & & & - & $r=-.32$ & $r=-.45$ \\
\hline $\begin{array}{l}\text { Pre-Post } \\
\text { flexibility } \\
\text { change }\end{array}$ & & & & & - & $r=-.30$ \\
\hline $\begin{array}{l}24 \text { to } 48 \text { hour } \\
\text { pain score } \\
\text { change }\end{array}$ & & & & & & - \\
\hline
\end{tabular}

\section{$\underline{\mathrm{Key}}$}

\section{PC: Pearson Correlation}

" $p<.05$

${ }^{* *} \mathrm{p}<01$

${ }^{* * *} \mathrm{p}<005$

$* * * * p<.001$ 
Table 10: Control Group $(n=18)$

\begin{tabular}{|l|r|r|r|r|r|r|}
\hline & $\begin{array}{c}\text { Pre- } \\
\text { exercise } \\
\text { stretch } \\
\text { score }\end{array}$ & $\begin{array}{c}\text { Post }- \\
\text { exercise } \\
\text { stretch } \\
\text { Score }\end{array}$ & $\begin{array}{c}24 \text { hour } \\
\text { post- } \\
\text { exercise } \\
\text { pain score }\end{array}$ & $\begin{array}{c}48 \text { hour } \\
\text { post- } \\
\text { exercise } \\
\text { pain score }\end{array}$ & $\begin{array}{c}\text { Pre-Post } \\
\text { flexibility } \\
\text { change }\end{array}$ & $\begin{array}{c}24 \text { to } 48 \\
\text { hour pain } \\
\text { score } \\
\text { change }\end{array}$ \\
\hline $\begin{array}{l}\text { Pre-exercise } \\
\text { stretch score }\end{array}$ & $-\mathrm{r}=.97^{* * * *}$ & $\mathrm{r}=-.11$ & $\mathrm{r}=.24$ & $\mathrm{r}=-.23$ & $\mathrm{r}=-.40$ \\
\hline $\begin{array}{l}\text { Post-exercise } \\
\text { stretch score }\end{array}$ & & & $\mathrm{r}=-.08$ & $\mathrm{r}=.29$ & $\mathrm{r}=-.01$ & $\mathrm{R}=-.41$ \\
\hline $\begin{array}{l}24 \text { hour post- } \\
\text { exercise pain score }\end{array}$ & & & - & $\mathrm{r}=.61$ & $\mathrm{r}=.18$ & $\mathrm{r}=.48$ \\
\hline $\begin{array}{l}48 \text { hour post- } \\
\text { exercise pain score }\end{array}$ & & & & & $\mathrm{r}=.20$ & $\mathrm{r}=-.39$ \\
\hline $\begin{array}{l}\text { Pre-Post flexibility } \\
\text { change }\end{array}$ & & & & & & $\mathrm{r}=-.01$ \\
\hline $\begin{array}{l}24 \text { to } 48 \text { hour } \\
\text { pain score change }\end{array}$ & & & & & & - \\
\hline
\end{tabular}

$\underline{\text { Key }}$

PC: Pearson Correlation

${ }^{*} \mathrm{p}<.05$

$* *$ p $<.01$

$* * * \mathrm{p}<.005$

$* * * * p<.001$ 


\section{CHAPTER IV \\ DISCUSSION}

Discussion of Results

The results of this study did not support the premise that either PNF or static stretching post exercise significantly reduces DOMS. Previous research indicates that there is no plausible evidence that any type of stretching reduces DOMS although PNF had not been specifically tested (Hebert \& de Noronha, 2009).

The correlations in the data suggested the possibility that the contraction phase of the PNF stretch may have placed a load on the already fatigued muscle group. Due to this load, the trained muscle may have become more damaged. Muscle defense mechanisms (e.g. muscle spindle and/or golgi tendon apparatus) may have been depressed allowing strain of the muscle.

Although the exact cause of DOMS is unknown, it has been suggested that DOMS is caused by micro tears (damage) in the muscle from unaccustomed eccentric exercises. Stretching muscle tissue is not believed to accelerate recovery of damaged muscles. It is important to know that not everyone suffers from DOMS after exercising. Traditionally, those who are accustomed to doing :pecific related exercise are less likely to suffer from intense DOMS (McArdle, Katch, \& Katch, 2007). Recommendations for avoiding DOMS include: concentric and isometric exercises, massage therapy, adapting the athlete to the DOMS inducing exercise, and rest (Hume, Cheung, Maxwell, \& 
Weerapong, 2004). During the 1960's and 1970's it was common to practice stretching before and/or after exercise to prevent soreness because during this period of time it was believed that DOMS was caused by spasms of the muscle. The spasms occurring in the muscle caused muscle contractions and muscle shortening. Stretching was taught to allow these muscles to elongate resulting in muscle elasticity (Udani, Singh, Singh, \& Sandoval, 2009).

Discussion of findings in the context of previous related research

In the review of literature, PNF stretching had not been tested as a possible mechanism to reduce DOMS. The majority of studies in the review of literature primarily focused on static stretching and its role on reducing DOMS. This study is the first to test PNF stretching and its relationship to DOMS. Initial research on the topic suggested that those who participate in static stretching after training achieve low levels of DOMS (Bobert, Hollander, \& Huijing, 1986); Wessel and Wan (1994) tested pre and post-exercise a series of static stretches after inducing DOMS on the quadriceps muscles. The stretching routine performed before and after eccentric exercise in this study did not reduce DOMS. Lund, Vestergaard-Poulsen, and Kanstrup (1998) also performed a DOMS inducing exercise on the quadriceps muscles followed by a static stretch routine. In this study, static streiching also did not have any significant influence on reducing DOMS in study participants.

Hebert and de Noronha (2009) suggested that stretching no longer needs to be researched because there is overwhelming evidence that pre- or post-exercise stretching static or ballistic stretching does not reduce DOMS. The results of this study appear to 
concur with Hevert and de Noronha (2009); PNF stretching appears not to be beneficial to one trying to alleviate DOMS.

\section{Study Limitations}

Some limitations of this study should be noted. The first limitation would be the convenience sample that volunteered to participate. Participants were college students at the University of North Dakota and the majority of participants were relatively close in age. This sample is not necessarily an exact representation of people at different universities or with different age demographics. Another limitation of this study is the type of study design. A posttest-only control group design was used for practical reasons (e.g. mortality rates). Different study design types such as a cross-ever or pretest-posttest control group design : suld be used to identify a longer time period participants are being tested. Another limitation involves the warm-up of the participants. Participants were allowed to choose how they warmed-up and for how long. Consistency lacks in this portion of the study. Participants should all do the same warm-up for the same period of time. Also, it may be suggested that participants perform a DOMS inducing exercise routine with more intensity. Performing 3 sets of seated leg curl may not be enough resistance training for one to achieve desired levels of DOMS.

Suggestions for Future Research

This study may be the first to evaluate the effects of post-exercise PNF streiching on DOMS. Therefore, further research can be conducted in this area. It is suggested that participants have a wider age and body composition. Testing PNF stretching and DOMS may also be tested by using a type of study design that includes a longer participation 
time for the participants. Future research should keep consistency on how participants warm-up. Finally, because the data collected in this study are new, the study should be duplicated in order to confirm the results were not a fluke.

\section{Conclusions}

Coaches should show concern for their athletes when they are suffering from DOMS. Athletes often are not physiologically and psychologically performing at their highest level when they are suffering from DOMS (Behm, Button, \& Butt, 2001). Also, DOMS may be an indication that the training load on an athlete/exerciser was excessive for a variety of reasons. An athlete is more likely to become injured when suffering from DOMS due to the muscle tissue damage (Ekstrand, Gillquist, \& Liljedah, 1983). It has been proposed that repeating sub-maximal bouts of exercise is not as effective as progressive training; however, fitness level of the individual being trained should be used as an indicator of how much to push (Chen, Chen, Lin, $W_{u}^{\prime} \&$ Nosaka, 2010). Coaches should consicer using the FIT principle where progressively train their athletes and slowly increase the time of the activity, intensity of the activity, and duration of the activity in order to avoid DOMS.

Excessive static stretching should be avoided as a warm up (Corbin \& Lindsay, 2005). The purpose of an active warm-up is to prevent injury, maintain current health status, enhance performance of the athlete(s), and to simulate competitive situations (Corbin \& Lindsay, 2005). Warming-up also increases muscle temperature and body core temperature resulting in increased muscle elasticity, decreased tension at the joints, greater release of oxygen in the body, increased metabolic activity, increased nerve 
conduction, increased thermoregulatory strain, increased oxygen consumption, increased blood flow with, and post activation muscle potential. Static stretching fails to increase the temperature of the muscle or the core temperature of the body. Stretching may increase muscle elasticity and tension at the joints; however, the increase in range of motion from stretching may decrease force production in the muscle due to the decrease tension in muscles. It is recommended that coaches prescribe activities for their athletes that ais of low intensity and increase the temperature of the muscles. The athlete can then benefit from warming-up. Static and PNF stretching may be recommended to cool down because the muscles are often warm from performing activities. This allows the muscle to have higher elasticity resulting in a better stretch. Stretching may also help release heat within the muscles. The primary benefit of stretching is to increase the elasticity of muscles and tendons resulting in decreased likelihood of injury. 
APPENDICES 
Appendix A

Pain Scale

Directions: Select the number which best indicates your current level of soreness.

1 Complete absence of soreness

2 Moderate pain felt only when touched/slight persistent pain

3 Light pain when walking up or down stairs

4 Light pain when walking on a flat surface/painful

5 Moderate pain, stiffness or weakness when walking/very painful

6 Severe pain that limits your ability to move/unbearably painful 
Appendix B

\section{INFORMED CONSENT}

TITLE: The Effects of Two Different Post-Exercise Stretching Modalities on Delayed Onset Muscular Soreness in Adults

PROJECT DIRECTOR:

PHONE H

DEPARTMENT:
Ryan McGrath

651-895-7570

Physical Education, Exercise Science, and Wellness

\section{STATEMENT OF RESEARCH}

A person who is to participate in the research must give his or her informed consent to such participation. This consent must be based on an understanding of the nature and risks of the research. This documen? provides information that is important for this understanding. Research projects include only subjects who choose to take part. Please take your time in making your decision as to whether to paricipate. If you have questions at any time, please ask.

\section{WHAT IS THE PURPOSE OF TEIS STUDY?}

You are invited to be in a research study about the effects of stretching on delayed onset muscular soreness (DOMS) because you fit the criteria for the study.

The purpose of this research study is to identify if some types of post-exercise stretching have the capability to reduce the typical delayed onset muscular soreness (DOMS) that occurs after unaccustomed resistance exercise. It is important to look at different ways to lower DOMS because, for some DOMS is a barrier to participation in healthful exercise.

\section{HOW MANY PEOPLE WILL PARTICIPATE?}

The goal is to recruit a total of 50-70 people. Students at the University of North Dakota and Jarnestown College have been invited to participate.

\section{HOW LONG WILL I BE IN THIS STUDY?}

Your total participation in the study will last about 48 hours 


\section{WHAT WLL HAPPEN DURIVG THIS STIDY?}

The study will proceed as follows:

- After a brief exf anation of the study you will be invited to compiete this consent form and a Physical Activity Readiness Questionnaire (PAR-Q). The PAR-Q is a brief questionnaire that screens individuals for their readiness to exercise.

- If you agree to participate and are cleared by the PAR-Q, the next stage will be a brief 510 rninute warm up consisting of simple calisthenics and jogging.

- Next will be a sit-and-reach stretch test which will measure the flexibility of the hanstring and lower back muscles.

- Following the sit-and-reach stretch test, you will be asked to do 3 sets of seatod leg curl as follows: first set will use a nominal we ght to familiarize you with the exercise, and enable judgment of subsequent resistance will be used. The second and third sets will utilize a resistance that should allow you to complete 8-15 repetitions. In each set you will be asked to lift the weight quickly but lower the weight more slowly over a 5 -second time count.

- Immediately after the sit-and-reach you will either be guided through some stretching exercises, or be informed the physical part of the procedures is over. This will be predetermined randomly so that the researchers can see if stretching makes a diffurence to any post-excrcise soreness that may occur.

- Finally, you will be given instructions on how to complete the brief muscle soreness questionnaire using the internet 24 , and 48 hours after the exercises are completed.

\section{WHAT ARE THE RISKS OF THE STUDY?}

You may experience the typical sorenes: in the hamstring muscles that occurs after unaccustomed resistance exercise. This soreness typically lasts about 48 hours post-traizang. During exercise, you may experience slight discomfort from exercising. You mey also experience cramping or muscle pulls in rare occurrences.

\section{WTAT ARE THE BENEFITS OF THS STUDY?}

You may not benefit personally from being in this study. However, in the future, other people might benefit from this study because those who do exercise may use the principies in this study to reduce DOMS in their exercise routine.

\section{WILL IT COST ME ANYTHENG TO BE IN THIS STUDY?}

You will not incur any costs for being in this research study. 


\section{WILL I BE PAID FOR PARTICIPATING?}

You will not be paid for being in this research study.

\section{CONFIDENTLALITY}

The data will be kept private to the extent permitted by law. In any report about this study that might be published, you will not be identified. Your study recond may be reviewed by Government agencies, the University of North Dakota Institutional Review Board, Jamestown College Institutional Review Boand, James Whitehead (advisor of researcher), Dennis Caine (Physical Education, Exercise Science, and Wellness department chair) or Ryan McGrath (principal investigator).

A.ny in formation that is obtained in this study and that can be identified with you will remain confidential and will be disclosed only with your permission or as required by law.

Confidentiality will be maintained by means of keeping all consent forms and data in separate folders which will be lociked in a file cabinet located in the Physical Education, Exercise Science, and Wellness (PXW) department at the University of North Dakota. You will be randomily assigned a number when you sign up for the study that will be kept confidential so the privacy of your name can be kept private. You and your data will be referred to as a number, not a name.

If we write a report or article about this study, we will describe the study results in a summarized manner so that you cannot be identified.

\section{COMPENSATION FOR INJURY}

In the event that this research activity results in an injury, treatment will be available including first aid, emergency treatment and follow-up care as needed. Payment for any such treatment is to be provided by you (you will be billed) or your third-party payer, if any (such as health insurance, Modicare, etc.) No funds have been set aside to compensate you in the event of injury. In addition, the study staff cannot be responsible if you knowingly and willingly disregerd the directions they give you

\section{IS TIIS STUDY VOLUNTARY?}

Your participation is voluntary. You may choose not to participate or you may discontinue your participation at any time without penalty or loss of benefits to which you are otherwise entitied. Your decision whether or not to participate will not affect your current or future relations with the University of North Dakota or Janestown College. You can decline this study at any time and you will not be contacted again about the study again.

If you decide 's leave the sudy early, we ask that you notify the researcher via c-mail or phone. 
You will be informed by the research investigater of this study of any significant new findings that develop during the study which may influence your willingness to continue to participate in the study.

\section{CONTACTS AND QUESTIONS?}

The researcher conducting this study Ryan McGrath. You may ask any questions you have now. If you later have questions, concerns, or complaints about the research please contact kyan McGrath at 651-895-7570 or by e-mail at ryan.mcgrath@urd.nodak.edu anytime. James Whitehead (principal investigator's advisor) may be contacted by phone at $701-777-4347$ or by e-mail at janıes.whitehead@und.nodak.edu.

If you have questions regarding your rights as a research subject, or if you have any concerns or complaints ahout the research, you may contact the University of North Dakota institutional Review Boarid at (701) 777.4279 or the Jamestown College Institutional Review Board at (701) $252-3467$ ext 2582. Please call these numbers if you cannot reach research $\mathrm{staff}_{8}$ or you wish to talk with someone eise.

Your signature indicates that this research study has been explained to you, that your questions have been an wered, and that you agree to take part in this study. You will receive a copy of this form.

Subjects Nanie:

Signature of Subject

Date

University of North Dakota Institutional Review Board Approved on OCT $\quad 5 \quad 2009$

Daic Expires on OCT 42010 
(A Questionmaire for People Aged 15 to 69)

Reguiar physical activity is fun and healthy, and increasingly more people are starting to become more active every day. Being more active is very safe for most people. However, some people should check with their doctor before they start becoming much more physically active.

If you are planning to become much more physically active than you are now, start by answering the seven questions in the box below. Hf you are between the ages of 15 and 69, the PAR-Q will tell you if you should check with your doctor before you start. If you are over 63 years of age, and you are not used to being very active, check with your doctor

Common sense is your best guide when you answer these questions. Please read the questions carefully and answer each one honestly: check YES or NO.

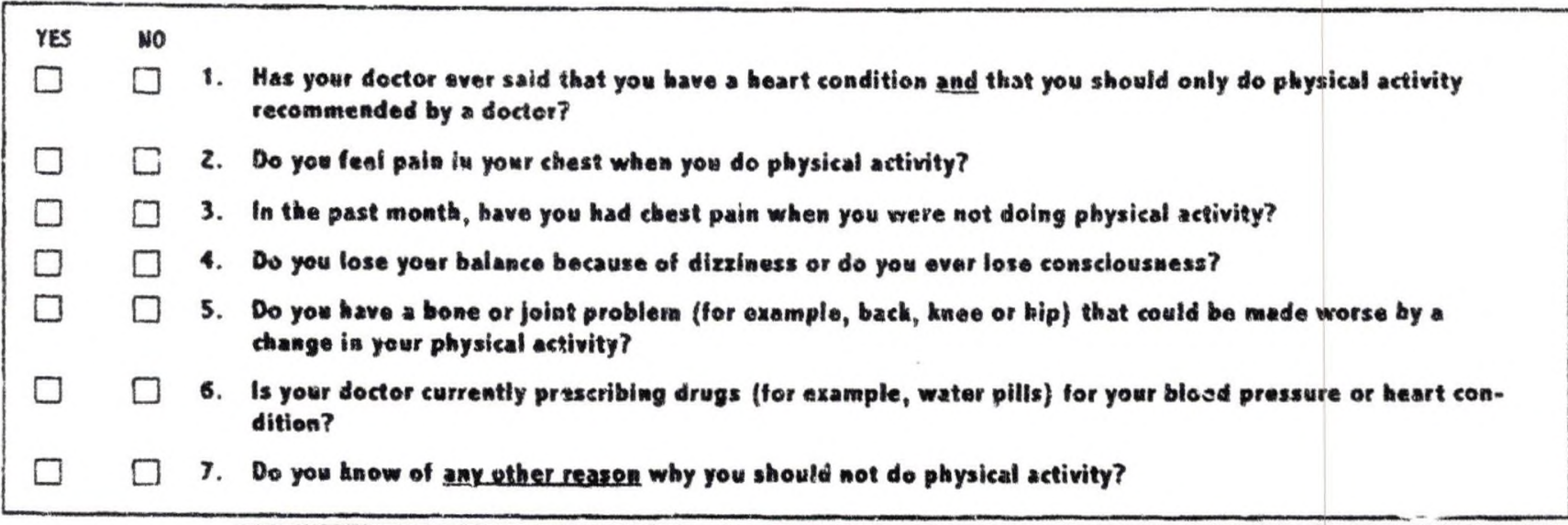

Talk with your doctor by phone or in person BEFORE you stert becoming much more physically active or BEFORE you have a fitness appraisal. Tell your doctor about the PAR-Q and which questions you answered YES.

- You may be able 10 do any activity you want - as long as you start slowly and build up gradually. Or, you may need to restrict your activties to those which are safe for you. Talk with your doctor about the kinds of activities you wish to partiripate in and follow hisfher advice.

- Find out which community programs are safe and helpful tor you.

\section{Wo to all questionis}

If you answered NO honestly to all PAR-Q questions, you can be reasonably sure that you can:

- starl becoming much more physically active - begin slowly and build up gradually. This is the satest and easiest way to go.

- take part in a fitness appraisal - this is an excellent way to determine your basic fitness so that you can plan the best way for you to live actively. It is also highly recommended that you have your blood pressure evaluated. If your reading is over 144/94, talk with your doctor before you start becoming much more physically active.

\section{DELAY BECOMIMG NHSH MOKE ACTVE: \\ - if you are not feeling well because of a temporary illness such as a cold or a fever - wait until you feel better; or \\ - if you are or may be pregnant - takk to your doctor before you starl becoming more active.}

PLEASE MOTE: If yosir healch changes so that you then answer YES to any of the above questions. tell your fitness or health prolessional. Ask whether you should chançe your physical activity plan.

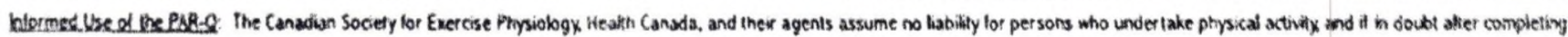
this westionarre. conuhl pout doctor prior to physical activity

\section{No changes permitted. You are enconraged to photocopy the PAR-Q but owly if you wse the entire form.}

NOTE $t 1$ the PAR-Q is beng given to a person before he or she partiopates in a physical activity program or a finess appraisal, this seciion may be used ior legal or administ ative purpeses

"I have read. understood and completed this questionnaire. Any questions I had were answered to my hill satisfaction."

NaMt

SKONATUN

Servivas of pater:

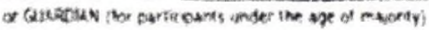

OAIE

WIXNSS

Wote: This phreical activity slasance is valid ios a maximem of 12 montha from the date it is completed and becomes ixwalid $\|$ your condtition changes so that you would answer YES to any of the seren guestions. 


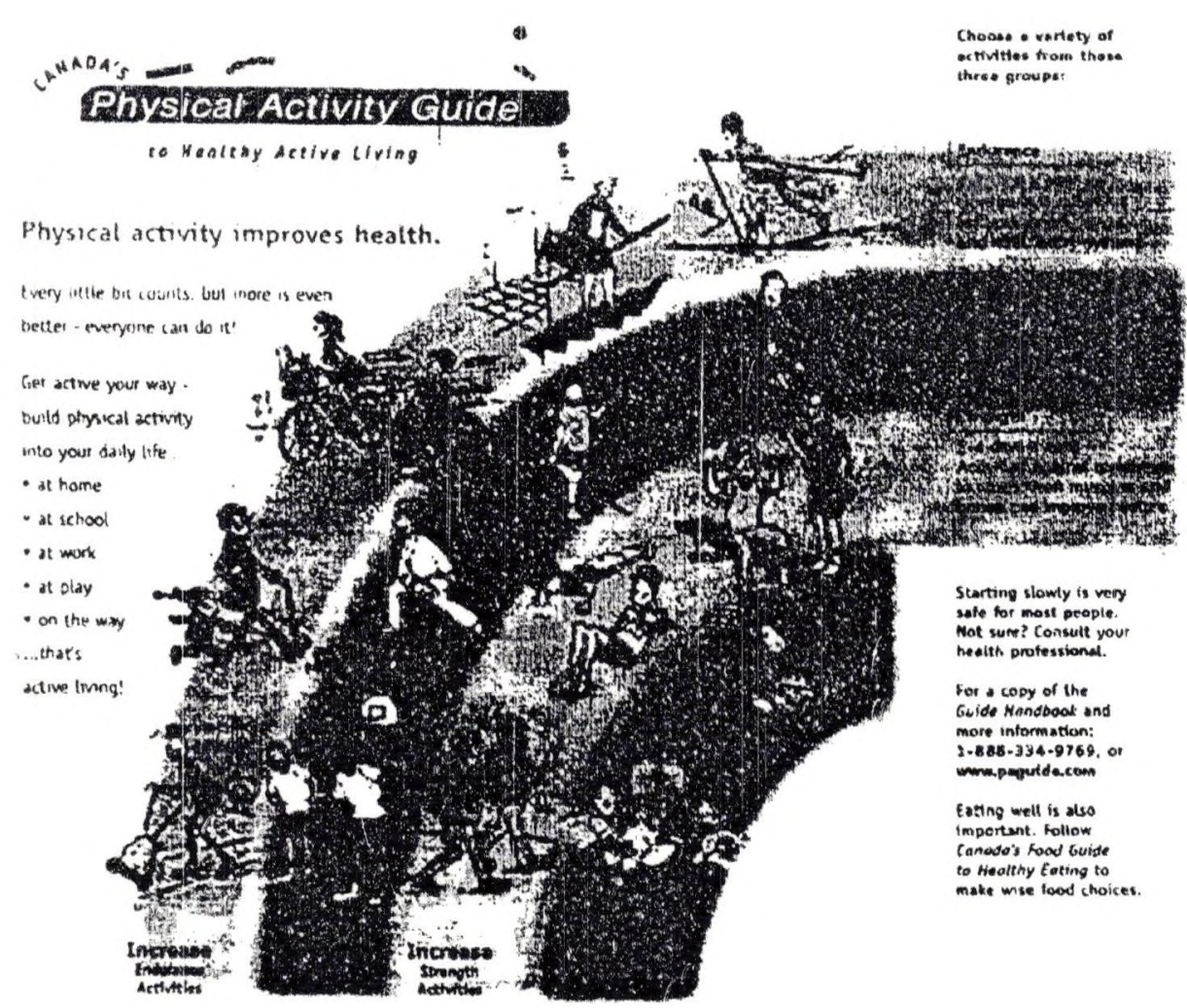

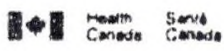

cyge. constien Socitety lor
Get Active Your Way. Every Day-For Life! Scientisis say sccumulala co minutes of phiyscal activity every day to stay heolithy or imptove your teasth. As You pragress of at least io minutes pach. Star slowty, and build wio.
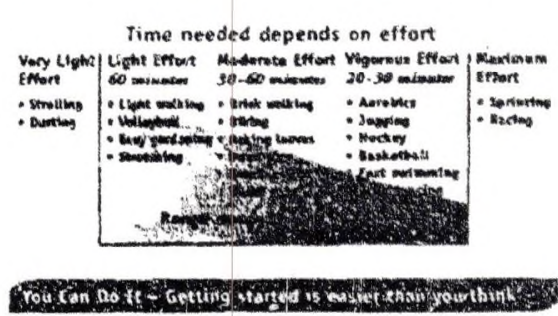

Physical activiny doen inave to be way hard. Build physest actwities into your asily roukina.

- Welk whenever you can-get. Siarl whth a 10 minuts watkoft the bus warky, the silirs gradualty ncreose the fine. insiead of the elovator.

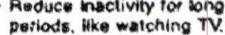
Gel up trom the couch ind streich ard bend for a lew minues every hout Play activeiy with you kids have to make sh longterm Choose to watk, wheel or commitment. $\begin{array}{ll}\text { cycle for shorl trips. } & \text { Co the activites you are doiro } \\ \text { nowe more often }\end{array}$

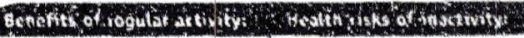

moner neaven bether poptures and bejenco

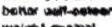

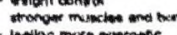

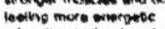

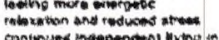

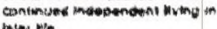

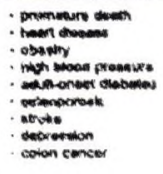

7.

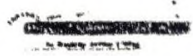

Source: Canada's Physical Activity Guide to Healthy Active Living. Health Canada. 1998 hlto:/lumu.hc-sc.gs.ca/hrob/paguidejodt/guideEng odf

(c) Reproduced with permission from the Menister of Public Works and Government Services Canada, 2002.

\section{FITMESS AHO HEALTM PROFESSIOWALS MAY BE INTERESTED IN THE IMFORMATION RELOW:}

The following companion forms are availatite for doctors' use by contacting the Canadian Society for Exercise Physiology (adoress below):

The Physical Activity Resdiness Madical Examination (PARaed-x) - to be used by doctors whth people who answer YES to one oi more Questions on the PAR-Q.

The Phraical Activity Readiaess Medlcal Examieation for Preganacy (PARomed-X for Preguancy) - 10 be used oy doctors with pregnant patients who wish to become more active.

Relerences:

Arraix. 6.A. Wigle. D.T., Mao, Y (1992). Risk As:essment of Physical Activity and Physical Fitness in the Canada Heath Survey

Follow-Up Study. 1. Cliw. Ephlemiol. 45:4 419.428.

Moltola, M. Wolle. L. A (1994). Active Living and Pregnancy, In: A. Quinney, L. Gauvin, T. Wall (eds.), Toward Active Living: Proceodizgs of ithe laterantional Conference on Physical Activity, Fitaess and Mealth. Champaign. Il: Human Kinetics.

PAR-Q Validation Report, British Columbia Ministry of Health, 1978.

Thomas, S. Reading, 1. Shephard, R.L. (1992). Revision of the Physical Activity Readiness Questionnaire (PAR-Q). Cax. 1. Spt. Sci. 17:4 338-345.

For more information, please contact the

\section{Canadian 5ociety lor Exercise Physiclogy \\ 202-185 Somer se: Street West \\ Ottawia, ON K2PO12}

Tel 1.877 .651 .3755 - $\mathrm{FAX}(613) 234.3565$

Onferic murcep.ca
The original PAR-Q was developed by the British Columbia Ministry of Health. Ii has been revised by an Expert Advisory Committee of the Canadian Society lor Exercise Physiology chaired by Dr. N. Gledhil (2002)

Disponible en français sous te tirre equestionnare sur "'aptitude a lactivite physique QAAP (revise 2002). 
REPORT OF ACTION: EXEMPTIEXPEDITED REVIEW

University of North Dakota Institutional Roview Board

Date: $\quad 9 / 23 / 2109$

Project Number:

IRB-200910-073

Principal Investigator: McGrath, Ryan

Department: PXW

Project Title: The Effects of Two Different Post-Exercise Stretching Modalities on Delayed Onset Muscular Soreness in Adults

The above referenced project was reviewed by a designated member for the University's institutional Review Board on

Detobar $5,-2009$ and the following action was taken:

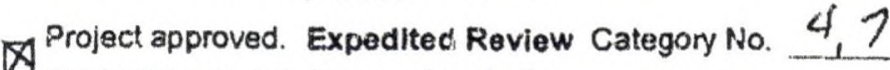

Next scheduled raviaw must ve before: ectober_4. 2010

Coples of the attached consent iorm with the IRB approval stamp dated must be used in obtaining consent for this study.

Project approved. Exempt Review Category No.

This approval is valid unill periodic review scheduled unless so stated in the Remarks Section.

Copies of the atteched consent form with the IRB approval stamp dated must be usisd in obtaining consent for this study.

Minor modifications required. The required correctiunsıadditions must be submitted to RDC for review and approval. This study may NOT be started UNTIL final IRB approval has been recelved.

$\square$ Project approval deferred. This study may not be started untll final IRB approval has been recelved.

(See Remarks Section for further information.)

Disapproved dlaim of exemption. This project requires Expedited or Full Board review. The Human Subjects

Review Form must be filled out and submitted to the IRB for review.

Proposed project is not human subject research and dces not require IRB review.

Not Research

Not Human Subject

PLEASE NOTE: Requested revislons for student proposals MUST include adviser's signature. All revisions MUST be highlighted.

Wf Education Requirements Completed. (Project cannot be started until IRB education requirements are met.)

(n)

(1)

cc: Or. James Whitehead

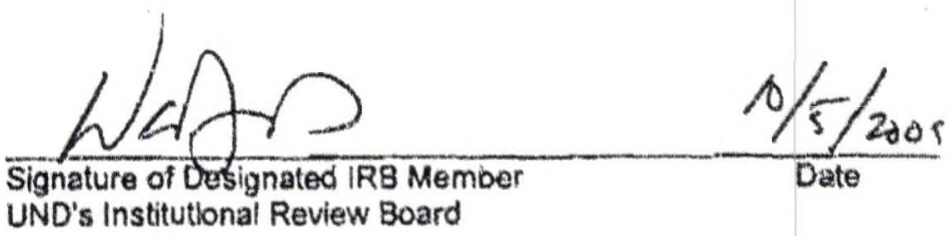

If the proposed project (clinical medical) is to be part of a research activity funded by a Federal Agency, a special assurance statement or a completed 310 Form may be required. Contact RDC to obtain the required docurnents.

(Revised 10/2005) 


\section{REFERENCES}

American College of Sports Medicine. (2000). ACSM's guidelines for exercise testing and prescription. American College of Sports Medicine, 6, 158.

Armstrong, R., Laughlin, M., Rome, L., \& Taylor, C. (1983). Metabolism of rats ruining up and down an incline. Journal of Applied Physiology, 55, 518-521.

Behm, D., Button, D., \& Butt, J. (2001). Factors affecting force loss with prolonged stretching. Canadian Society for Exercise Physiology, 26, 261-272.

Bobbert, M., Hollander, A., \& Huijing, P. (1986). Factors in delayed onset muscular soreness of man. Medicine \& Science in Sports \& Exercise, 18, 75-81.

Brooks, G., Fahey, T., \& Baldwin, K. (2005). Exercise physiology: human hioenergetics and its applications. New York: McGraw-Hill Companies. Inc.

Campbell, D., Stanley, J. (1963). Experimental and quasi-experimental designs for Research. Chicago: Rand McNally College Publishing Company. 
Chen, T., Chen, H., Lin, M., Wu, C., \& Nosaka K. (2010). Potent protective effect Conferred by four bouts of low-intensity eccentric exercise. Medicing \& Science In Sports \& Exercise, 42, 1004-1012.

Cheung, K., Hume, P., \& Maxwell, L. (2003). Delayed onset muscle soreness: treatment Strategies and performance factors. Sports Medicine, 33, 145-164.

Corbin, C., \& Lindsey, R. (2005). Fitness for Life. Champaign: Human Kinetics.

DeVries, H., \& Housh, T. (1995). Electromyographic fatigue thresholds of the superficial muscles of the quadricepts femoris. European Journal of Applied Physiology, 71, 1439-6327.

Ekstrand, J., Gillquist, J., \& Liljedah. S-O. (1983). Prevention of soccer injuries. American Journal of Sports Medicine, 11, 116-120.

Edington, D., \& Edgerton, V. (1976). Physiology of exercise: for physical education, athletics and exercise science. Boston: Houghton Mifflin.

Gleim, G., Stachenfeld, N., \& Nicholas, J. (1990). The influence of flexibility on the economy of walking and jogging. Journal of Orthopedic Research, 8, 814-823.

Gulick, D., Kimura, I., Sitler, M., Paolone, A., \& Kelly, J. (1996). Various treatment techniques of signs and symptoms of delayed onset muscle soreness. Journal of Athletic Training, 31, 145-152. 
Hakkinen, K., Kallinen, M., İquierdo, M., Jokelainen, K., Lassila, H., Malkia, E., Kremer, W., Newton, R., \& Alen, M. (1998). Changes in agonist-antagonist EMG, muscle CSA, and force during strength training in middle-aged and older adults. Journal of Applied Physiology, 84, 1341-1349.

Hartig, D., \& Henderson, J. (1999). Increasing hamstring flexibility decreases lower extremity overuse injuries in military basic trainees. American Journal of Sports Medicine, 27, 173- 176.

Hebert, R., \& de Noronha, M. (2009). Stretching to prevent or reduce muscle soreness after exercise. Cochrane Database of Systematic Reviews, 1, 1-32.

Hebert, R., \& Gabriel, M. (2002). Effects of stretching before and after exercising on muscle soreness and risk of injury. $B M J, 325,1-5$.

Hedrick, A. (1993). Flexibility and the conditioning program. National Strength and Conditioning Association Journal, 15, 62-66.

Higbie, E., Cureton, K., Warren, G., \& Prior, B (1996). Effects of concentric and Eccentric training on muscle strength, cross-sectional area, and neural activation. Journal of Applied Physiology, 5, 2173-2181. 
High, D., Howley, E., \&Franks, B. (1989). The effects of static stretching and warm-up on prevention of delayed onset muscle soreness. Research Quarterly for Exercise and Sport. 60, 357-361.

Hume, P., Cheung, K., Maxwell, L., \& Weerapong, P. (2004). DOMS: an overview of treatment strategies. International Sports Medicine Journal, 5, 98-118.

Kent, M. (1998). The oxford dictionary of sports science and medicine. New York: The Oxford University Press Inc.

Lewis, S., Haller, R., Cook, J., \& Nunnally, R. (1985). Muscle fatigue in McArdle's disease studied by 31P-NMR: effect of glucose infusion. Journal of Applied Physiology, 59, 1991-1994.

Lund, H., Vestergaard-Poulsen, P., \& Kanstrup, I-L. (1998). The effect of passive stretching on delayed onset muscle soreness and other detrimental effects following eccentric exercise. Scandinavian Journal of Medicine and Science in Sports, $8,216-221$.

McA.rkle, W., Katch, F., \& Katch, V. (2007). Exercise physiology: energy, nutrition and human performance. Baltimore: Lippincott Williams \& Wilkins.

McAtee, R. (2007). Facilitated Stretching. Champaign: Human Kinetics. 
Moraska, A. (2007). Therapist education impacts the nassage effect on postrace muscle recovery. Medicine and Science in Exercise and Sport, 39, 34-37.

Plowman, S., \& Smith, D. (2003). Exercise physiology for health, fitness, and Performance. Glenview: Pearson Education Inc.

Pollok, M., Gaesser, G., Butcher, J., Despres, J-P., Dishman, R,. Franklin, B., \& Garber, C. (1998). The recommended quantity and quality of exercise for developing and maintaining cardiorespiratory and muscular fitness, and flexibility in healthy adults. Medicine \& Science in Sports \& Exercise, 975-991.

Pope, R., Herbert, R. Kirwan, J. \& Graham, B. (2000). A randomized trial of preexericse Stretching for prevention of lower-limb injury. Medicine \& Science in Sports \& Exercise, 32, 271-277.

Rahmama, N., Rahmani-Nia, F, \& Ebrahim, K. (2005). The isolated and combined erects of selected physical activity and ibuprofen on delayed-onset muscle soreness. Journal of Sports Sciences, 23, 843-850.

Reisman, S., Walsh, L., \& Proske, U. (2005). Warm-up stretches reduce sensations of stiffness and soreness after eccentric exercise. Medicine and Science in Sport and Exercise, 36, 929-936. 
Rodenburg, J., Steenbeek, D., \& Schiereck P. (1994). Warm-up, stretching and massage

diminish harmful effects of eccentric exercise. Inte»national Journal of Sports Medicine, 15, 414-419.

Sady, S., Wortman, M., \& Blanke, D. (1982). Flexibility training: ballistic, static or proprioceptive neuromuscular ficilitation. Archives of Physical Medicine and Rehabilitation, 63, 261-263.

Shrier, I. (2004). Does stretching improve performance? Clinical Journal of Sports Medicine, 14, 267-273.

Smith, M., Fryer, G. (2008). A comparison of two muscle energy techniques for increasing Flexibility of the hamstring muscle group. Journal of Bodywork Movement Therapies, 12, 312-317.

Thomas, J., Nelson, J., \& Silverman, S. (2005). Research methods in physical activity. Champaign: Human Kinetics.

Udani, J., Singh, B., Singh, V., \& Sandoval, E. (2009). BounceBack capsules for . eduction of DOMS after eccentric exercise: a randomized, double-blind, placebo-controlled, crossover pilot study. Journal of the International Society of Sports Nutrition, 6, !-6. 
Wessel, J., \& Wan, A. (1994). Effect of stretching on the intensity of delayed-onset muscle soreness. Clinical Journal of Sport Medicine, 4, 83-87.

Woodrow, K., Friedman, G., Siegelaub, A., Collen, M. (1972). Pain tolerance: differences according to age, sex and race. Psychosomatic Medicine, 34, 548-556.

Worrell, T., Smith, T., \& Winegardner, J. (1994). Effect of hamstring stretching on hamstring muscle performance. Journal of Orthopedic Sports Physical Therapy, 20, 154-159.

Zainuddin, Z., Newton, M., Sacco, P., \& Nosaka, Kazunori. (2005). Effects of massage on delayed-onset muscle soreness, swelling, and recovery of muscle function. Journal of Athletic Training, 40, 174-180. 